OPEN ACCESS

Edited by:

Sara Labiano,

University of Lausanne, Switzerland

Reviewed by:

Asis Palazon,

CIC bioGUNE, Spain

Romain Vuillefroy De Silly,

University of Lausanne, Switzerland

*Correspondence:

Salem Chouailb

salem.chouaib@gmu.ac.ae Salem.CHOUAIB@gustaveroussy.fr

${ }^{\dagger}$ These authors have contributed equally to this work

${ }^{\ddagger}$ These authors share senior authorship

Specialty section:

This article was submitted to Cancer Immunity and Immunotherapy,

a section of the journal

Frontiers in Immunology

Received: 01 October 2020 Accepted: 30 November 2020

Published: 20 January 2021

Citation:

Abou Khouzam R, Brodaczewska K, Filipiak A, Zeinelabdin NA, Buart S,

Szczylik C, Kieda $C$ and Chouaib S

(2021) Tumor Hypoxia Regulates Immune Escape/Invasion: Influence

on Angiogenesis and Potential

Impact of Hypoxic Biomarkers

on Cancer Therapies.

Front. Immunol. 11:613114.

doi: 10.3389/fimmu.2020.613114

\section{Tumor Hypoxia Regulates Immune Escape/Invasion: Influence on Angiogenesis and Potential Impact of Hypoxic Biomarkers on Cancer Therapies}

\author{
Raefa Abou Khouzam ${ }^{1}$, Klaudia Brodaczewska ${ }^{2 \dagger}$, Aleksandra Filipiak ${ }^{2,3 \dagger}$ \\ Nagwa Ahmed Zeinelabdin ${ }^{1}$, Stephanie Buart ${ }^{4}$, Cezary Szczylik ${ }^{5}$, Claudine Kieda ${ }^{2,6 \neq}$ \\ and Salem Chouaib ${ }^{1,4^{*}}$ \\ 1 Thumbay Research Institute for Precision Medicine, Gulf Medical University, Aiman, United Arab Emirates, ${ }^{2}$ Laboratory of \\ Molecular Oncology and Innovative Therapies, Military Institute of Medicine, Warsaw, Poland, ${ }^{3}$ Postgraduate School of \\ Molecular Medicine, Medical University of Warsaw, Warsaw, Poland, ${ }^{4}$ INSERM UMR 1186, Integrative Tumor Immunology \\ and Genetic Oncology, Gustave Roussy, EPHE, Faulty. De médecine Univ. Paris-Sud, University Paris-Saclay, Villejuif, \\ France, ${ }^{5}$ Centre of Postgraduate Medical Education, Department of Oncology, European Health Centre, Otwock, Warsaw, \\ Poland, ${ }^{6}$ Centre for Molecular Biophysics, UPR CNRS 4301, Orléans, France
}

The environmental and metabolic pressures in the tumor microenvironment (TME) play a key role in molding tumor development by impacting the stromal and immune cell fractions, TME composition and activation. Hypoxia triggers a cascade of events that promote tumor growth, enhance resistance to the anti-tumor immune response and instigate tumor angiogenesis. During growth, the developing angiogenesis is pathological and gives rise to a haphazardly shaped and leaky tumor vasculature with abnormal properties. Accordingly, aberrantly vascularized TME induces immunosuppression and maintains a continuous hypoxic state. Normalizing the tumor vasculature to restore its vascular integrity, should hence enhance tumor perfusion, relieving hypoxia, and reshaping anti-tumor immunity. Emerging vascular normalization strategies have a great potential in achieving a stable normalization, resulting in mature and functional blood vessels that alleviate tumor hypoxia. Biomarkers enabling the detection and monitoring of tumor hypoxia could be highly advantageous in aiding the translation of novel normalization strategies to clinical application, alone, or in combination with other treatment modalities, such as immunotherapy.

Keywords: microenvironment, angiogenesis, hypoxia, vessel, normalization, tumor suppressors, signatures

\section{INTRODUCTION}

The tumor microenvironment is a complex system, playing an important role in tumor development and progression. Besides cellular stromal components, extracellular matrix fibers, cytokines, and other metabolic mediators are also involved $(1,2)$. Among the microenvironmental factors that play a dominant role in neoplasia, hypoxia is believed to be one of the most relevant in the neoplastic 
response of tumor cells (3). It is widely appreciated that the majority of malignancies create a hostile hypoxic microenvironment that can hamper cell-mediated immunity and dampen the efficacy of the immune response $(4,5)$. Hypoxia, as an integral component of the tumor microenvironment and especially of the pathologically vascularized zones inside solid tumors contributes to immune tolerance of tumor cells by impeding the homing of immunocompetent cells into tumors and inhibiting their antitumor efficacy (6).

It is established that the endothelial response to tumor hypoxia signaling is the angiogenic switch involving HIF- $1 \alpha$ stabilization and transcription, along with production of VEGFs, angiopoietin 2, IL-8, and other factors. As antiangiogenic treatments have shown that destruction of angiogenesis leads to deep hypoxia and induces tumor resistance (7), efforts are focusing on rendering the tumor vessels functional to help treat the tumor $(8,9)$. By normalizing vessels, the challenge is to alleviate hypoxia to counteract most deleterious effects related to tumor microenvironment (Figure 1).

Normalization of vessels is a strategy to: first allow a new delivery of red blood cells, thus balancing the oxygen partial pressure inside the capillaries, and reducing the activity of the enzymatic pathways that sense the $\mathrm{pO}_{2}$ low level; second, to down regulate the hypoxia-activated molecular cascades that make the vessels chaotic and permeable, thus reducing the ability to maintain a flow in the capillaries (10). While normalized, vessels allow the blood borne molecules and cells to reach the internal part of the tumor site. As such, they permit the use of therapeutic strategies among which immunotherapies (11). Moreover, the consequences of such a normalization on the availability of $\mathrm{O}_{2}$ are deeply influencing the reactional balance by acting on soluble factors, regulating the extracellular matrix molecules and their activity, and impacting the metabolism and phenotype of the cells inside the microenvironment of the tumor cells (TME), as well as exocrine and paracrine signals.

Regulation of angiogenesis and recovery from its pathologic state is the challenge to which tumor suppressor molecules by their activation, may bring a considerable mean to progress. In the angiogenic process the PTEN molecule is a key regulator which orchestrates the structure of the vessels $(12-14)$. This places endothelial PTEN as a key target for normalization strategies.

Given the negative outcome associated with tumor hypoxia, a major goal has been recently to identify hypoxic tumors through a number of different approaches. In this regard, several hypoxia signatures have been reported and used to classify patient tumors into high-hypoxia and low-hypoxia, based on a hypoxia score generated from the expression of the signature genes in tumor samples (15-18). This would presumably enable

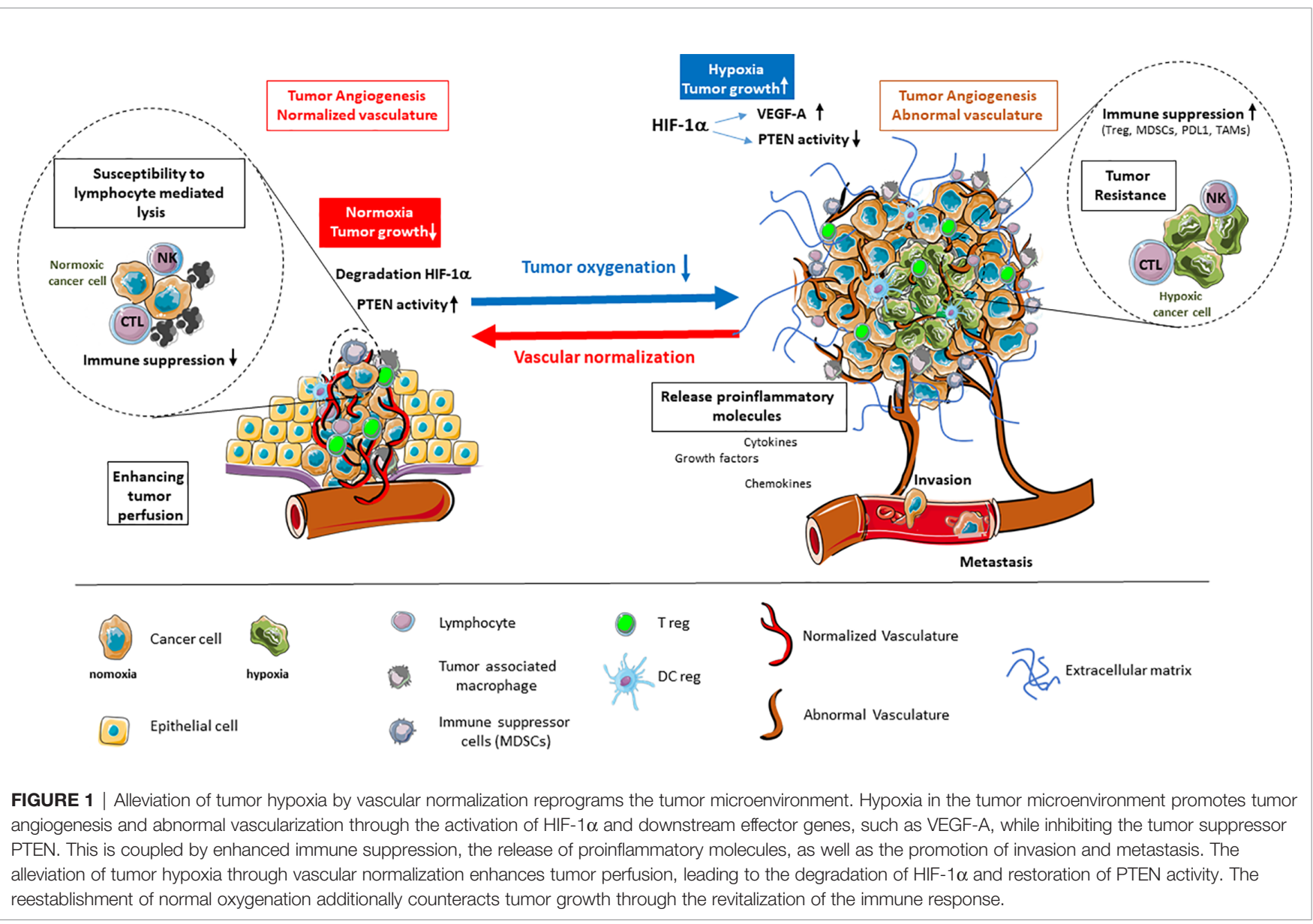


the clinical development of personalized, hypoxia-based therapies, which will, ultimately, improve outcomes in particular in cancer immunotherapy.

We will discuss available data on the relationship between hypoxia- and immune-related genes, how they are in most cases linking tumor hypoxia with an immunosuppressed state in cancer patients and more importantly have the potential to generate prognostic information. Clearly tumor hypoxia is a key component of TME interfering with the angiogenic axis, the remodeling of vessel architecture, function and immune reaction. In this respect, hypoxia signatures should be further considered as potential biomarkers that may lead to significant progress in the field of cancer immunotherapy.

\section{HYPOXIA IN THE TUMOR MICROENVIRONMENT PROMOTES ANGIOGENESIS}

In the context of solid tumors, microenvironment is characterized by a network of cancer cells, resident, recruited stromal and immune cells, as well as non-cellular components of the extracellular matrix (ECM) $(1,19)$. The crosstalk occurring among these various elements, through direct contacts and through an array of soluble factors, nurtures a dynamic TME in which altered tumor and host cell phenotypes are acquired $(1,2)$.

The early stages of tumor development are characterized by highly proliferating tumor cells which are aided in their growth and epithelial-mesenchymal transition by cancer associated fibroblasts (CAFs). These cells arise from resident fibroblasts or from other progenitor cells, including smooth muscle cells, pericytes, and bone marrow-derived mesenchymal cells (20-22). The endothelial cell and pericyte populations in the TME are required for the switch of a tumor mass from an avascular growth phase to an angiogenic phase to support the growing tumor demands for oxygen and nutrients $(23,24)$. The resulting tumor vasculature has been described as haphazardly shaped with various degrees of leakiness and irregularities compared to normal surrounding vasculature (25). Regarding immune cells, the degree of tumor infiltration and the type of immune cells, being tumor promoting, such as tumor associated macrophages and myeloid derived stromal cells, or tumor inhibiting, such as NK cells and cytotoxic T cells, varies greatly (26). Indeed, the environmental and metabolic pressures in the TME have a key role in molding tumor development by impacting the nature of stromal and immune cell fractions, TME composition and activation state $(2,23,27)$. In addition, non-cellular elements including components of the ECM, $\mathrm{pH}$, and $\mathrm{pO}_{2}$ are of key importance in cancer development (28).

\section{Hypoxia in the Tumor Microenvironment Repurposes Tumor Cells, Instigating Angiogenesis}

Hypoxia has been reported to exist in most solid tumors, manifesting when the diffusion of oxygen from surrounding vasculature is no longer adequately supporting the hyperproliferating tumor cells (29,
30). To sustain their energy, tumor cells need aerobic glycolysis, switching from metabolizing glucose through oxidative phosphorylation, to metabolizing it through glycolysis (Warburg effect) $(31,32)$. This process releases byproducts, such as lactic acid and carbonic acid, which if left unchecked would decrease intracellular $\mathrm{pH}$ resulting in acidosis (33). Hypoxia promotes transcriptional reprogramming of tumor cells with the aim of surpassing the detrimental environment of low oxygen and low $\mathrm{pH}$ levels. Such reprogramming is primarily executed by hypoxia inducible factors (HIFs) family of transcription factors. HIFs function as heterodimers composed of an oxygen-sensitive $\alpha$-subunit (HIF- $\alpha$ ) and a constitutive $\beta$-subunit (HIF- $\beta$ ). HIF- $\alpha$ exists in three isoforms, namely HIF- $1 \alpha$, HIF- $2 \alpha$, and HIF- $3 \alpha$, among which HIF- $1 \alpha$ is at the forefront of the cellular response to hypoxia (30, 34-36).

With respect to angiogenesis, HIFs have been described as master regulators of this process (35). In particular, HIF-1 induces the expression of a range of pro-angiogenic genes, including VEGF (vascular endothelial growth factor), PGF (placenta growth factor), ANGPT-2 (angiopoietin-2), CXCL-12 (chemokine C-X-C motif ligand12), also referred to as SDF-1 (stromal-derived factor-1) and PDGF-B (platelet-derived growth factor-B). These factors are critical for facilitating the angiogenic switch in tumors upon binding their respective receptors on the surface of endothelial cells, pericytes, and vascular smooth muscle cells (35-38).

The most potent hypoxia pro-angiogenic factor is VEGF-A $(36,39)$. VEGF-A, -B, -C, -D, and PGF, are secreted and act on endothelial cells by binding VEGFR (VEGF receptor)-1 and -2 (38). This activates pathways that promote endothelial cell proliferation and survival, such as the ERK (extracellular regulated kinase) and PI3K (phosphatidylinositol 3-kinase)/ AKT (protein kinase B) pathways (40); endothelial cell migration, like Rho GTPases (41); and ECM degradation for invasion and sprouting via expression of MT-MMP (membrane type matrix metalloproteinase) MMP-2, MMP-9, and urokinase plasminogen activator $(40,42)$. In addition, VEGF-A plays a key role in vascular permeability that is required for normal tissue homeostasis (43). Vascular hyper-permeability, due to the increased interstitial pressure in the tumor, enhances extravasation of tumor cells into the blood circulation and their metastasis (44). Indeed, while physiological angiogenesis gives rise to functional vessels, those arising in tumors are abnormal in structure and function, leading to inadequate tumor perfusion $(35,38,45)$.

\section{Pseudohypoxia and VHL}

Von Hippel-Lindau (pVHL) is an important tumor suppressor, which operates in the cell as a complex in which components are bound directly or indirectly to the pVHL (46-48). One of the most important roles of pVHL as E3 ubiquitin ligase is its targeted binding to HIF-1 $\alpha$ when prolyl residues 402 and 564 are hydroxylated for oxygen-dependent proteolysis (49-51). In cancer, mutations of pVHL are frequently observed (52). Mutated or lost VHL gene, prevents participation of pVHL in the E3 ubiquitin ligase complex and interaction with its HIF- $1 \alpha$ substrate, allowing stabilization of HIF- $1 \alpha$ even in physiological levels of oxygen (53). This phenomenon is called "pseudohypoxia" 
i.e. induction of similar molecular mechanisms by VHL mutation as during exposure to non-physiological, low $\mathrm{pO}_{2}$ (described in previous section). Forty-six to $82 \%$ of sporadic cases of RCC are characterized by VHL mutations that result in the dysregulation of HIF-1 downstream genes, like VEGFs, PDGF, and TGF $\alpha$ and high angiogenic activity in these tumors (52). RCC patients with either VHL mutation (54) or high VEGF-A level (55) are characterized by poor prognosis. Indeed, similar to hypoxia, pseudohypoxia, exacerbates cancer progression and maintains a deep control on the TME, characterized by a strong immunosuppression (56) and a strong disturbance of the cell microenvironmental conditions.

\section{Hypoxia and PTEN-Mediated Regulation of Angiogenesis}

PTEN is a tumor suppressor and genome keeper, its frequent mutation or deletion in cancer (57) is responsible for cell cycle deregulation and reprogramming $(58,59)$. PTEN deficiency and hypoxia synergistically condition the composition and organization of tumor microenvironment $(60,61)$. Hypoxic condition effectively maintains a low PTEN level and even slight changes in the doses of active PTEN cause deep effects in cancer. This is fundamental for the angiogenic process. Indeed, PTEN is the main regulator of vessel formation because it rules the cross-talk between DLL4 in the tip cells and $\mathrm{NOTCH}$ in the stalk cells, signaling for migration and growth respectively (14) as a function of the $\mathrm{pO}_{2}$ level (62).

As a tumor suppressor gene, PTEN is a tool to regulate the tumor microenvironment and a key target molecule for angiogenesis-based immunotherapeutic approaches. In fact, vessel normalization through PTEN activation in endothelial cells has several positive consequences. The first is $\mathrm{pO}_{2}$ increase, due to blood flow establishment, which increases the active form of endothelial PTEN. Secondly, targeting the active PTEN is a strategy to maintain vessels normalization, aiming to increase the efficacy of anticancer treatments including the new immunoregulating strategies (12).

\section{IMPACT OF HYPOXIA ON THE ANTITUMOR IMMUNE RESPONSE AND FUNCTIONAL CONSEQUENCES OF VASCULAR NORMALIZATION}

\section{Hypoxia Interferes With Antitumor Immune Response}

The role of tumor hypoxia in the recruitment of immunosuppressive cells and the regulation of their functions is becoming evident. Tumor hypoxia impacts the antitumor immune response by promoting local immune suppression and inhibiting immune killing functions. In fact, hypoxic zones in solid tumors are infiltrated by a large number of the most widely studied immunosuppressive cells within the tumor microenvironment including myeloid derived stromal cells (MDSCs), tumor-associated macrophages (TAMs), and Tregulatory (Treg) cells (63). The hypoxia transcriptional factor HIF- $1 \alpha$ has been directly shown to regulate the function and differentiation of MDSCs within the hypoxic TME. In this regard, we have provided evidence indicating that tumor-derived MDSCs are more immunosuppressive than splenic MDSCs mostly because of the induction of HIF-1 $\alpha$-dependent increased arginase activity and nitric oxide production. In addition, we showed that tumoral MDSC expression of PD-L1 is upregulated under hypoxia and increased MDSC-mediated T cell tolerance (64). In this respect, we, and others (65) further provided evidence that HIF-1 $\alpha$ regulates the expression of PD-L1 by binding directly to a hypoxia response element in the PD-L1 proximal promoter.

TAMs have also been found to be preferentially located in tumor hypoxic areas, where they accumulate HIF-1 and HIF-2 (66). Furthermore, it has been reported that HIF-1 and HIF-2 play a role in the promotion of macrophage angiogenic properties $(67,68)$. It should be noted that dendritic cells (DCs) are also diverted by hypoxia from their highly specialized antigen-presenting and $\mathrm{T}$ cell-activating functions. In this regard, hypoxia has been reported to inhibit the stimulatory capacity of DCs for activating T cell functions (69). On the contrary, the production of proinflammatory cytokines, such as TNF and IL-1, as well as the inflammatory C-C chemokine receptor (CCR) type 5 (CCR5), was strongly upregulated under hypoxia in DCs (70). Moreover, several studies indicate that the maturation and function of DCs are influenced by several hypoxia-modulated factors, such as VEGF present in the tissue microenvironment. The production of VEGF-A by human tumors inhibits the functional maturation of DCs and, thereby, promotes immune escape of tumor cells (69). With respect to Tregs induction and immunosuppressive function, hypoxic stress has been reported to upregulate Foxp3 through direct binding of HIF-1 to the Foxp3 promoter region, inducing Treg cell formation (71). Facciabene reported that tumor hypoxia also attracts Treg cells inside the tumor bed by impacting the cytokine profile (72). Furthermore, hypoxic stress results in an increased expression and secretion of CCL28 by ovarian tumor cells, which acts as a chemoattractant for Treg cells. In a previous report, we have demonstrated that hypoxic stress, by inducing the pluripotency factor NANOG in tumor cells, activates the expression and secretion of the tumor immunosuppressive TGF- $\beta 1$ by a mechanism involving at least direct binding of NANOG to the TGF- $\beta 1$ promoter (73). Further, targeting this factor decreases TGF- $\beta 1$ and reverses the intra-tumoral immune cell infiltrate by increasing the number of CD8+ $\mathrm{T}$ cells and decreasing the number of macrophages and Treg cells (73) in mice melanoma. These findings connect stem cell-associated factors with inhibition of the immune response in the hypoxic tumor environment.

It should be noted that the precise molecular mechanisms by which hypoxia alters the balance between growth-promoting inflammation and the antitumor immune response is not fully understood. Although the role of hypoxia in the induction of immunosuppression is unquestionable, it remains however complex and sometimes contradictory with respect to its role in promoting antitumor immunity. Very recently, HIF- $1 \alpha$ expression was reported to correlate with increased tumor immune and stromal signatures and aggressive phenotypes in 
human cancer (74). Doedens et al. provided elegant data indicating that elevated HIF-1 and HIF-2 support the function of cytotoxic CD8+ T-cells (75). Tyrakis et al. have suggested a role for HIF- $1 \alpha$ in CD8+ T-cell proliferation, differentiation, and antitumor activity through the regulation of L-2HG (76). In addition, HIF-1 was found to contribute to natural killer cell priming and activation via regulation of the glycolytic rate (77). Clearly more studies should be directed towards a better understanding of the precise molecular mechanisms by which hypoxia alters the balance between growth-promoting inflammation and the antitumor immune response.

\section{Barriers Posed by the Hypoxia- Angiogenesis Axis}

Hypoxia in tumors is the first signal to proximal and distal endothelial cells (ECs) to undertake angiogenesis. It modulates the expression by endothelial cells of several adhesion molecules like E- and P-selectins, ICAM-1, VCAM, which are responsible for leukocyte trafficking (78-80). Thus hypoxia modifying the endothelial cell properties in the tumor, causes reduction of immune cell infiltration (81), maintains anergy of endothelial cells, their unresponsiveness to pro-inflammatory stimuli (82, 83), and reduced adhesion molecules levels (84). Both ICAM-1 and VCAM are low in EC in the tumors (85-87). Upon normalization of pathological angiogenesis, adhesion receptors are upregulated on ECs (88). ICAM-1 (89) or VCAM (90) are reexpressed and $\mathrm{T}$ cell infiltration into the tumor is also restored (91), as shown during the course of anti-VEGF therapy (92). Moreover, low migration of $\mathrm{T}$ cells into the tumor due to overexpression of the endothelin $\mathrm{B}$ receptor $(\mathrm{ET}(\mathrm{B}) \mathrm{R})$ on ECs was reverted by ET(B)R blocking, which restored immune cell infiltration by ICAM-1 activity (93).

Another important endothelial regulator of anti-cancer immune response is PD-L1/PD-1 axis (94). During recruitment, $\mathrm{CD} 8+\mathrm{T}$ cells binding to endothelial PD-L1 leads to downregulation of lymphocyte activation (95). Simultaneously, PD-L1 expressing ECs can support the suppressive functions of Tregs $(96,97)$. Given that PD-L1 is upregulated on tumor endothelial cells $(94,98)$, this contributes to make the pathogenic vessels a barrier for the development of a protective immune response in the tumor (99).

\section{Vascular Normalization Strategies vs Anti- Angiogenic Therapies}

Vascular normalization strategy takes into consideration restoring the leaky, abnormal blood vessels that feed tumors. This aims to alleviate tumor hypoxia which would result in improvement of drug delivery, induction of an efficient anti-tumor immune response, and inhibition of cancer stem cells differentiation (100).

The often used antiangiogenic drugs are selective tyrosine kinase inhibitors (TKIs) that target pro-angiogenic receptors, such as endothelial growth factor receptors (VEGFR) family and Platelet-derived growth factor receptors (PDGFR) (101, 102). The use of TKIs significantly improved survival of patients suffering from certain types of cancers, such as renal cell carcinoma, hepatocellular carcinoma and colorectal carcinoma
(101). In various types of treatment it was demonstrated that TKI's can normalize vessels $(103,104)$. Moreover, treatment of breast cancer patients with bevacizumab induced the recruitment of pericytes to vessels, strengthening them in the primary tumor, and decreasing levels of circulating biomarkers VEGF, and Ang2 (105), typical for hypoxia. This observation and knowledge that pericytes may express VEGFs as survival factor for neighboring ECs (106), led to the conclusion that more mature vessels may acquire independence from tumor-secreted VEGF-A, which may show resistance to bevacizumab (107). Altogether, vessel normalization has a huge positive impact on the tumor microenvironment, by increasing blood perfusion, alleviating tumor hypoxia, and reducing vessel leakiness resulting in increased vessel maturity. However, in such therapies the effects of vessel normalization were transient, and not effective for all types of cancer (100). To overcome the disadvantage of hypoxia-related limitations of antiangiogenic therapies, some approaches are emerging that emphasize stable normalization without excessive pruning of vessels and will be discussed (12).

As VEGF-A is the key inducer of angiogenesis, researchers designed a gene therapy based on a soluble form of the VEGF receptor-2 (sVEGFR2) (108-110) to trap and neutralize overproduced VEGFs. Such a strategy resulted in reduction of tumor growth and inhibition of pathological angiogenesis. Another strategy to normalize vessels was devoted to the oxygen sensing enzymes that regulate HIF- $1 \alpha$ stability, namely the three prolyl hydroxylases (PHD1-3) enzymes (12, 111). Recently, several PHD inhibitors have been developed and evaluated in clinical trials $(112,113)$; studies on Lewis lung carcinoma showed that such inhibitor can normalize the TME, improving vessel maturation and reducing hypoxia (113).

A distinct approach to overcome hypoxia and normalize vessels is to use myo-inositol trispyrophosphate (ITPP), which is a membrane-permeant allosteric effector of hemoglobin (114). Human microvascular endothelial cells (MECs) (115), cultured in hypoxia in the presence of red blood cells (RBCs) pre-treated with ITPP, do not form "vessel like" structures as control cells. Moreover, markers of hypoxia such as HIF- $1 \alpha$ and VEGF-A were dramatically reduced by $\mathrm{O}_{2}$ delivery ITPP-loaded RBCs upon rolling onto the endothelial cell layer in hypoxic conditions. Such results confirmed that ITPP enhances the capacity of $\mathrm{Hb}$ to release bound oxygen, which alleviates hypoxia and may be applied to reduce the extent of the pathological angiogenesis (116). Melanoma and breast cancer studies using ITPP-based treatment proved the vessels normalization properties of this molecule. Vessel maturation and strengthening were obtained, due to recruitment of pericytes and induction of VEGF-R2 in response to the pericyte/EC cross-talk. Maturation of vessels was also confirmed by upregulation of Tie-2 protein and upregulation of endothelial cell junctions. Long-term treatment with ITPP reduced PHD1-3, VHL, HIF-1, HIF-2, and HO-1 (tumor protective enzyme), which suggests stable reoxygenation of tumors (12). Moreover, ITPP treatment reduced selection of the cancer stem cell population and dissemination of cells from tumor, by downregulating CD133, MDR1, Oct-4 and Osteopontin. In addition, ITPP treatment led to a significant reduction in the 
number of cells expressing Glut-1, LDH and CAIX, showing that ITPP also regulates glycolysis in the TME (12).

Important elements of the TME that are involved in angiogenesis are endothelial precursor cells (EPCs), which include subpopulations of cells with different functional capacities. Recently, it has been shown that developed endothelial precursor cells (117) injected intravenously can be recruited to the tumor microenvironment site $(109,118)$. This process is mimicking the behavior of circulating progenitor cells during cancer development (109). Nowadays cell-based therapies are becoming more relevant $(119,120)$ and considering the homing properties of endothelial precursor cells $(109,121)$, it could be possible to engineer such early EPCs that would carry therapeutic genes and targeting angiogenesis (109, 122, 123). Collet et al. confirmed this hypothesis (118). Consequently, stable vessel normalization is confirmed to improve tumor microenvironment, in contrast to antiangiogenic therapy where normalization is only transient.

\section{Impact of Hypoxia on Transient vs Stable Normalization}

As highlighted above, vessel normalization indeed modifies the tumor microenvironment, wherein the improved pericyte recruitment and upregulation of endothelial cell junctions allows for stable and mature vessels with decreased leakiness and proper perfusion (124). The key result of this phenomenon is reduction of hypoxia and $\mathrm{pH}$ increase in cancer microenvironment. Given that hypoxia induces selection of aggressive and metastatic cells, its reduction should inhibit the selection of cancer stem-like cells (CSCs). This was indeed observed in the tumor site following vessel normalization, as was the reduction in metastasis $(12,111)$.

There are several strategies that target vessel normalization, but only those which stabilize vessels constantly can give better therapeutic effects. As described in a previous section, an important role in stable vessel normalization is played by tumor suppressor PTEN in endothelial cells. This protein is one of the key regulators of proliferation of endothelial cells, it inhibits vessel sprouting and tube-like structures formation. PTEN was discovered to be very often mutated in cancer diseases (125). Overexpression of PTEN resulted in inhibition of angiogenesis and of tumor growth (126). This evidence suggested that targeting PTEN may be crucial in achieving stable vascular normalization. ITPP by its pyrophosphate structure was a good candidate to activate endothelial PTEN, which down regulates the PDK/PI3K/AKT/mTOR pathway and controls the angiogenesis process. This result was confirmed by downregulation of LOX protein which is involved in inhibiting PTEN expression (12).

\section{POTENTIAL APPLICATION OF HYPOXIA BIOMARKERS IN GUIDING VASCULAR NORMALIZATION STRATEGIES}

Stable vascular normalization strategies can be aided in their transition from the preclinical to the clinical setting through the availability of biomarkers for patient selection and treatment monitoring. A biomarker is defined based on the clinical question it addresses (7, 127). For vascular normalization, biomarkers that can delineate appropriate patient cohorts and that allow monitoring of response are essential for minimizing unwarranted side-effects and maximizing therapeutic efficacy. Hallmarks of vascular normalization entail improved vascular integrity through decreased permeability, and enhanced tumor perfusion, which alleviates tissue hypoxia (7, 127). Detecting changes in these phenomena has been accomplished through the determination of several imaging parameters and circulating plasma/serum markers and have recently been reviewed in the context of anti-angiogenic therapy (7, 127, 128). Herein, we discuss how combinational approaches considering the hypoxic state of the tumor as well as immune infiltration could prove impactful as surrogate biomarkers for the success of vascular normalization.

\section{Detection of Hypoxia in the Context of Vascular Normalization}

Alleviation of hypoxia is a prolific end-result of an intact tumor vasculature and there are several methods by which this phenomenon can be detected in tumors, including immunohistochemical staining for intrinsic protein markers of hypoxia, notably CAIX, VEGFA, and HIF-1 $(129,130)$, as well as the extrinsic molecule pimonidazole (131). This reagent binds cellular macromolecules upon injection into patients, forming stable adducts with reduced proteins in conditions of low oxygen, that can then be detected by immunohistochemistry indicating hypoxic sites (131). Apart from these tissue-based markers, several imaging approaches have been designed for mapping tumor hypoxia in a non-invasive manner and some of these techniques have additionally been integrated to simultaneously monitor tumor vascular normalization.

Direct quantification of oxygen levels has been successfully achieved in vivo by applying both non-imaging electron paramagnetic resonance (EPR) oximetry and EPRI (imaging) approaches (132-134). Examination of tumor blood flow, prefusion or transient vascular normalization coincided with tumor oxygenation levels measured by these techniques in multiple pre-clinical cancer models (135-139). EPR oximetry requires the respective implantation of an exogenous particulate or the injection of a soluble agent into the tumor to quantify $\mathrm{pO}_{2}$ $(132-134,140)$. Detection is therefore limited to superficial tumors; however investigations to assess and put forth safer and more informative oxygen sensors that can work at any tissue depth are ongoing $(133,141-143)$, and some are being applied in clinical studies (144). Regarding EPRI, the recent introduction of nontoxic, water-soluble, and biocompatible paramagnetic probes could lead to its clinical translation, enabling the non-invasive, real-time quantification of $\mathrm{pO}_{2}$ in a three-dimensional format $(134,140,145)$. Nonetheless, work remains to be done to alleviate safety concerns in human subjects, and to provide appropriate tools for human application (146).

Blood oxygenation level-dependent magnetic resonance (BOLD-MRI), which indicates oxygen saturation in the blood, 
and its counterpart, tissue oxygen level dependent (TOLD)-MRI, which measures local tissue oxygen concentration, have shown high potential as non-invasive qualitative indicators of tumor oxygenation (147). BOLD-MRI has recently been used in a colon cancer xenograft model treated with antiangiogenic agents; wherein an increase in the measured oxygen parameter, reflecting hypoxia relief, matched the transient vascular normalization, indicated by dynamic contrast enhanced magnetic resonance imaging (DCE-MRI) (148). DCE-MRI is a technique that has been applied in clinical trials for antiangiogenic therapy (127), as it enables monitoring tumor perfusion and vascular permeability (149). Vascular perfusion measured by DCE-MRI was verified to occur in an inverse manner to hypoxia in xenografts of pancreatic ductal carcinoma (150), patient-derived xenograft models of cervical cancer (151) and primary liver cancer (149). Such findings underscore the relevance of determining hypoxia reversal as a proxy indicator of mature and functional tumor vasculature.

Hypoxia can indirectly be assessed by applying computed tomography (CT) and positron emission computed tomography (PET) in combination with radiotracers. PET/CT has been applied with the radiolabeled glucose analogue ${ }^{18} \mathrm{~F}$ fluorodeoxyglucose (FDG), which distinguishes cells in the TME based on their glucose metabolism, with preferential accumulation in hypoxic and slowly dividing cells (152). ${ }^{18} \mathrm{~F}$ FDG PET/CT measures both hypoxia and metabolism and this technique has primarily been used in the clinic for tumor visualization, staging, restaging and monitoring treatment (152-154). Indeed due to its hypoxia selectivity, ${ }^{18} \mathrm{~F}$ fluromisonidazole is the most widely used PET tracer for detecting tissue hypoxia in patient studies $(130,155) .{ }^{18} \mathrm{~F}$ FMISO-PET relies on the entrapment of nitroimidazole compounds in hypoxic cells upon binding intracellular macromolecules (130), which allows for 3D visualization of intra-tumoral hypoxia. Preclinical studies have shown the utility of this technique in monitoring vascular normalization by highlighting the alleviation of hypoxia $(12,156)$. The application of ${ }^{18} \mathrm{~F}$-FMISO-PET with other imaging modalities in glioblastoma showed that tumor hypoxic zones overlapped with hypervascularization $(157,158)$, however these vessels were characterized by abnormal permeability (159). This is consistent with the expected vascular integrity in hypoxia-driven angiogenesis (25). These studies further highlight the link between an abnormal tumor vasculature and hypoxia, reaffirming the utility of hypoxia indicators in monitoring vascular normalization

The interplay between hypoxia and angiogenesis is not a straightforward cause and effect relationship, as such spatial heterogeneity between hypoxic zones and degree of perfusion also exists in tumors $(154,160,161)$. In particular, a pilot study on head and neck cancer patients that underwent ${ }^{18} \mathrm{~F}$-FMISO dynamic PET (dPET), wherein hypoxia and perfusion were simultaneously determined at distinct time points, reported random trends between hypoxia and perfusion in the same tumor (160). In addition, a study on a small cohort of breast cancer patients that applied a multimodal imaging approach, revealed a negative association between ${ }^{18} \mathrm{~F}$-FMISO-PET measured hypoxia and markers of vascular function and perfusion indicated by DCE-MRI; however there were areas that displayed one characteristic but not the other (161).

Taken together, for imaging methods to be applied to determine hypoxia relief as a proxy to vascular normalization, a multimodal approach that allows for extracting data on both phenomena might be the best route. Moreover, the reported relationship between hypoxia and vascularization is evidently tumor dependent, necessitating the testing and standardization of imaging parameters and thresholds as per cancer type.

\section{Relevance of Gene Signatures and Hypoxia Score in Defining a Tumor's Hypoxic State}

Hypoxia gene signatures have been derived to capture the multifaceted and heterogeneous transcriptional response to hypoxia across a range of solid tumors and have been nominated for potential clinical application as the next surrogate biomarker for hypoxia (15-18).

Hypoxia signatures have been used to classify patient tumors into high-hypoxia and low-hypoxia, based on a hypoxia score generated from the expression of the signature genes in tumor samples $(16,18)$. Alternatively, patients have been stratified according to a hypoxia risk score, which takes into consideration both the expression of each gene and the coefficient representative of its prognostic relevance (162-168). Despite the variety of methods used in both deriving and applying the signatures, the dichotomization of patient data based on hypoxia scores has generated strong prognostic power; wherein patients having deeply hypoxic tumors, experienced worse survival parameters [reviewed in (18)]. Moreover, at least four hypoxia signatures have shown predictive power of response to the addition of hypoxia modifying therapy to radiotherapy, or the addition of bevacizumab to neoadjuvant chemotherapy (Table 1). In all cases, the presence of hypoxia predicted improved response and when an interaction test with the treatment arm was performed, there was a significant difference in response to the combination therapy between the more hypoxic and less hypoxic tumors (Table 1). In addition, the increased ratio of expression of two hypoxia related genes was found to correlate with the absence of response to anti-PD1 in a small cohort of melanoma patients (174). Some of these are even being investigated in ongoing clinical intervention trials for head and neck (NCT01950689, NCT01880359, NCT02661152) and cervical (NCT04275713) cancers (175).

Among the published signatures, a 15-gene signature (176) (Table 2) has been put forth as the best performer, showing high robustness in its ability to define a hypoxic state across different cancer types $(177,178)$. This signature has been applied to report on the molecular underpinnings (179) and mutational load (180) distinguishing high hypoxia and low hypoxia tumors in a pancancer setting. Moreover, it has been utilized to highlight distinct molecular features and their correlation with sensitivity to anticancer drugs in around 10,000 tumors classified based on 
TABLE 1 | Predictive hypoxia gene signatures.

\begin{tabular}{|c|c|c|c|c|c|c|}
\hline $\begin{array}{l}\text { Hypoxia } \\
\text { signature }\end{array}$ & Patients ${ }^{\#}$ & Therapy§ & Endpoint & $\begin{array}{l}\text { Statistical } \\
\text { test }\end{array}$ & $\begin{array}{l}\text { Impact of hypoxia on } \\
\text { combination therapy }\end{array}$ & $\begin{array}{c}\text { Interaction between } \\
\text { hypoxia and treatment } \\
\text { arm }\end{array}$ \\
\hline $\begin{array}{l}\text { 15-gene } \\
(169)\end{array}$ & $\begin{array}{l}323 \text { patients with head and neck } \\
\text { squamous cell carcinoma from the } \\
\text { DAHANCA } 5 \text { trial }\end{array}$ & Radiotherapy +/- CON & $\begin{array}{l}\text { Locoregional } \\
\text { failure }\end{array}$ & $\begin{array}{l}\text { Multivariate } \\
\text { Cox } \mathrm{PH} \\
\text { analysis }\end{array}$ & $\begin{array}{l}\mathrm{HR}=0.42 ; 95 \% \mathrm{Cl} \\
0.25-0.68 ; \mathrm{P}=0.0001\end{array}$ & $P=0.003$ \\
\hline $\begin{array}{l}\text { 26-gene } \\
(170)\end{array}$ & $\begin{array}{l}157 \text { patients with T2-T4 laryngeal cancer } \\
\text { from the ARCON trial }\end{array}$ & Radiotherapy +/- CON & $\begin{array}{l}\text { Regional } \\
\text { control }\end{array}$ & $\begin{array}{l}\text { Univariate Cox } \\
\mathrm{PH} \text { analysis }\end{array}$ & $\begin{array}{l}\mathrm{HR}^{\star}=0.14 ; 95 \% \mathrm{Cl} \\
0.03-0.62 ; \mathrm{P}=0.009\end{array}$ & - \\
\hline $\begin{array}{l}\text { 24-gene } \\
(171)\end{array}$ & 185 patients with locally advanced bladder & Radiotherapy +/- CON & $\begin{array}{l}\text { Local relapse } \\
\text { free survival }\end{array}$ & $\begin{array}{l}\text { Univariate Cox } \\
\mathrm{PH} \text { analysis }\end{array}$ & $\begin{array}{l}\mathrm{HR}=0.47 ; 95 \% \mathrm{Cl} \\
0.26-0.86 ; \mathrm{P}=0.015\end{array}$ & $P=0.0094$ \\
\hline $\begin{array}{l}\text { 28-gene } \\
(172)\end{array}$ & carcinoma from the BCON trial & Radiotherapy +/- CON & Overall survival & $\begin{array}{l}\text { Univariate Cox } \\
\mathrm{PH} \text { analysis }\end{array}$ & $\begin{array}{l}\mathrm{HR}=0.54 ; 95 \% \mathrm{Cl}: \\
0.32-0.91 ; \mathrm{P}=0.021\end{array}$ & $P=0.0026$ \\
\hline $\begin{array}{l}\text { 3-gene } \\
(173)\end{array}$ & $\begin{array}{l}289 \text { patients with HER2-negative breast } \\
\text { cancer from the GeparQuinto trial }\end{array}$ & $\begin{array}{l}\text { Neoadjuvant } \\
\text { chemotherapy +/- } \\
\text { bevacizumab }\end{array}$ & $\begin{array}{l}\text { Pathologic } \\
\text { complete } \\
\text { response }\end{array}$ & $\begin{array}{l}\text { Multivariate } \\
\text { logistic } \\
\text { regression }\end{array}$ & $\begin{array}{l}\mathrm{OR}=2.40 ; 95 \% \mathrm{Cl}: \\
1.28-4.51 ; \mathrm{P}=0.006\end{array}$ & $P=0.023$ \\
\hline
\end{tabular}

${ }^{\#}$ Randomized phase III trials: DAHANCA 5, The Danish head and neck cancer; ARCON, accelerated radiotherapy with carbogen and nicotinamide; BCON, bladder carbogen nicotinamide; GeparQuinto: Bevacizumab, Everolimus (RAD001), and Lapatinib as Neoadjuvant Chemotherapy Regimes for Primary Breast Cancer.

${ }^{\S} \mathrm{CON}$ : carbogen and nicotinamide as hypoxia modifying therapy.

*Values taken from (16).

$\mathrm{PH}$, proportional hazard; HR, hazard ratio; Cl, confidence interval; OR, odds ratio.

TABLE 2 | 15-gene Buffa hypoxia signature (176).

\begin{tabular}{|c|c|c|}
\hline $\begin{array}{l}\text { HGNC } \\
\text { Symbol }\end{array}$ & Gene Name & Function \\
\hline ACOT7 & acyl-CoA thioesterase 7 & Lipid metabolism \\
\hline$A D M$ & adrenomedullin & Angiogenesis \\
\hline$A L D O A$ & aldolase, fructose-bisphosphate A & Glucose metabolism \\
\hline CDKN3 & cyclin dependent kinase inhibitor 3 & Cellular proliferation \\
\hline ENO1 & enolase 1 & Glucose metabolism \\
\hline$\angle D H A$ & lactate dehydrogenase $\mathrm{A}$ & Glucose metabolism \\
\hline MIF & $\begin{array}{l}\text { macrophage migration inhibitory } \\
\text { factor }\end{array}$ & Inflammation \\
\hline MRPS17 & mitochondrial ribosomal protein S17 & Mitochondrial translation \\
\hline NDRG1 & N-myc downstream regulated 1 & Stress response \\
\hline P4HA1 & prolyl 4-hydroxylase subunit alpha 1 & ECM remodeling \\
\hline PGAM1 & phosphoglycerate mutase 1 & Glucose metabolism \\
\hline SLC2A1 & solute carrier family 2 member 1 & Glucose uptake \\
\hline TPl1 & triosephosphate isomerase 1 & Glucose metabolism \\
\hline TUBB6 & tubulin beta 6 class $V$ & $\begin{array}{l}\text { Cytoskeleton } \\
\text { organization }\end{array}$ \\
\hline VEGFA & vascular endothelial growth factor & Angiogenesis \\
\hline
\end{tabular}

their hypoxia status (178). Indeed, the application of hypoxia signatures in this manner highlights their utility in representing tumor hypoxia and their relevance in classifying patient tumors based on their hypoxic state.

Recently, the genes themselves were interrogated through an integrative analysis that assessed the correlation between the expression of each of the 15 genes with their methylation status and copy number variations (CNVs), among other features, in pan-cancer data and in repositories of cancer cell lines (181). All genes presented with CNVs, and their expression levels were reflective of their decreased promoter methylation in most cancers. Of relevance, the genes were associated with increased activation of oncogenic signaling pathways, and enrichment of malignant behaviors reflective of hypoxia, invasion and EMT
(181). Furthermore, they acted as risk factors in more than half of gene-cancer pairs, supporting their cancer promoting role (181). $V E G F A, S L C 2 A 1$, and $L D H A$ are three of these genes that play central roles in angiogenesis (VEGFA) and glucose metabolism (SLC2A1 and LDHA) by encoding for VEGF, GLUT-1, and LDHA, respectively. As described earlier, these proteins are reduced post-ITPP vascular normalization (12); therefore the presence of such genes in hypoxia signatures underlines their potential to inform on the state of vascular normalization.

The concept of describing the hypoxic state of a tumor using a score that can determine a patient's prognosis and guide their treatment trajectory is a highly attractive notion, however the published signatures require prospective clinical validation (16). Another consideration would be defining the cutoffs to be used for indicating the degree of tumor hypoxia, as well as understanding what control genes to integrate for quantifying gene expression and setting up the appropriate assays accordingly $(16,182,183)$. Of relevance, a recent study compared the ability of distinct gene expression methodologies (qPCR, nCounter, and GeneChip) to score patients from two retrospective head and neck squamous cell carcinoma (HNSCC) cohorts of the DKTK-ROG (German Cancer Consortium Radiation Oncology Group), using three distinct hypoxia gene signatures, as well as other signatures (184). Based on expression data availability from the examined techniques, they reported on similar classification of patients as having more hypoxic or less hypoxic tumors. In addition, for the two signatures that had expression data from all three techniques, there was high concordance in the association of the scores from the signatures with disease locoregional control (184). This study underscores the robustness of gene panels in stratifying patients and their transferability across various quantification techniques (184).

It should be noted that hypoxia gene signatures have a measurable advantage due to their multiparametric nature. By integrating genes with varying hypoxia sensitivities and 
spatiotemporal dependency, they could buffer out discrepancies that would otherwise arise with single hypoxia indicators (183, 185). This has been shown in HNSCC $(182,185)$ and cervical cancer (183), where in comparison to single markers of hypoxia, multigene signatures showed stronger refractory power to intratumor heterogeneity. While such findings need to be confirmed for other cancer types as well, they support the notion that hypoxia scoring can be done using the same diagnostic tumor biopsy. This has an additional advantage of negating the need for radioactive contrast agents and tracers as those required by imaging.

A caveat to consider with hypoxia gene signatures is that they are primarily based on signaling pathways that are downstream of HIF1, limiting their application in tumors harboring HIF activating mutations, including those with VHL mutations. Moreover, while they mark the presence of hypoxia, gene signatures do not give information on oxygenation levels. Despite these hurdles, a recent study on cervical cancer showed that combining a hypoxia gene signature with DCE-MRI, resulted in an improved and more informative evaluation of hypoxia related resistance to chemoradiotherapy (175). Therefore, it could be speculated that in vascular normalization strategies, hypoxia signatures could provide a supplementary datapoint about the TME that could prove valuable when applied alone or in conjunction with other imaging approaches, to assess the reversal of an abnormal tumor vasculature. Given that a normalized vasculature is expected to reprogram the tumor immune microenvironment as well, integrating immune markers could have an additional role in guiding approaches for vascular normalization.

\section{Combinational Transcriptomic Indicators of Hypoxia and Immunity}

Assessment of the immune conditions of the tumor microenvironment has been carried out in glioma (163), hepatocellular carcinoma (HCC) (164), and lung adenocarcinoma (165), following their biphasic stratification into hypoxia high-risk and hypoxia lowrisk groups (Table 3). Immune cell populations were determined and compared in the two groups using the analytical tool CIBERSORT (Cell-type Identification By Estimating Relative Subsets Of RNA Transcripts), which relies on the gene expression matrix of 547 genes to delineate 22 immune cell types in the TME (186). Distinct immune populations were shown to dominate in the high-risk and the low-risk groups in the tested cohorts (163-165) (Table 3). In particular, the high-risk groups in the HCC and GB datasets both showed higher prevalence of immune cells associated with an immunosuppressive TME, including Treg and M0 or M2 macrophages $(163,164)$. This was coupled by an increase of immune activating cell populations, NK cells, CD8+ $\mathrm{T}$ cells, and M1 macrophages, in the HCC hypoxia low-risk group (164) (Table 3). Further comparing the expression of immunosuppressive cytokines and immune checkpoints in GB,

TABLE 3 | Immune cell populations in tumors grouped based on hypoxia risk scores.

\begin{tabular}{|c|c|c|c|c|c|c|}
\hline \multirow[t]{2}{*}{ Immune cell population" } & \multicolumn{6}{|c|}{ Comparison between hypoxia-high and hypoxia-low risk groups ${ }^{\S}$} \\
\hline & GB-High risk & HCC-High risk & LUAD-High risk & GB-Low risk & HCC-Low risk & LUAD-Low risk \\
\hline B cell naïve & - & $P=0.266$ & $P=0.088$ & - & & $P=0.51$ \\
\hline B cell memory & - & $P=0.468$ & & - & & $P<0.001 ; P=0.025$ \\
\hline Plasma cells & - & $P=0.411$ & $P=0.515$ & - & & $P=0.323$ \\
\hline T cells CD8 & - & & $P=0.436$ & - & $P=0.072$ & $P=0.519$ \\
\hline T cells CD4 naïve & - & - & $P=0.989 ; P=0.38$ & - & - & \\
\hline T cells CD4 memory resting & $P=0.001 ; P=0.001$ & & & & $P=0.082$ & $P<0.001 ; P=0.012$ \\
\hline T cells CD4 memory activated & - & & $P<0.001 ; P<0.001$ & - & $P=0.226$ & \\
\hline T cells follicular helpers & - & $P=0.606$ & $P=0.857 ; P=0.132$ & - & & \\
\hline T cells regulatory & $P=0.006 ; P<0.001$ & $P=0.077$ & & & & $P=0.265 ; P=0.56$ \\
\hline $\mathrm{T}$ cells gamma delta & - & $P=0.727$ & $P=0.384 ; P=0.09$ & - & & \\
\hline NK cells resting & $P=0.009 ; P<0.001$ & $P=0.992$ & $P<0.001 ; P<0.001$ & & & \\
\hline NK cells activated & - & & $P=0.426 ; P=0.672$ & $P<0.001 ; P=0.683$ & $P=0.004$ & \\
\hline Monocytes & - & $P=0.673$ & & - & & $P=0.001 ; P=0.001$ \\
\hline Macrophages MO & $P=0.001 ; P=0.03^{\neq}$ & $P<0.001$ & $P<0.001 ; P<0.001$ & & & \\
\hline Macrophages M1 & & & $P<0.001 ; P=0.02$ & & $P=0.011$ & \\
\hline Macrophages M2 & & & & & $P=0.526$ & $P=0.845 ; \mathbf{P}=\mathbf{0 . 0 4}$ \\
\hline Dendritic cells resting & - & $P=0.856$ & & - & & $P<0.001 ; P<0.001$ \\
\hline Dendritic cells activated & - & $P=0.134$ & $P=0.308$ & - & & $P=0.193$ \\
\hline Mast cells resting & - & & & - & $P<0.002$ & $P<0.001 ; P<0.001$ \\
\hline Mast cells activated & - & $P=0.081$ & $P<0.001 ; P=0.013$ & - & & \\
\hline Eosinophils & - & $P=0.093$ & $P=0.409$ & - & & $P=0.489$ \\
\hline Neutrophils & $P<0.001 ; P=0.001$ & $P=0.002$ & $P=0.035$ & & & $P=0.167$ \\
\hline
\end{tabular}

\#Expression of the immune cell populations was derived based on the analytical tools CIBERSORT (Cell-type Identification By Estimating Relative Subsets Of RNA Transcripts) (163-165).

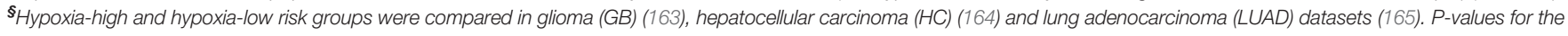
increasing immune populations in each group are presented. Two $P$-values are presented for GB and LUAD, which included two independent datasets. $P$-values $<0.05$ were considered statistically significant and are presented in bold.

*Increase was reported for tumor associated macrophages in total (163).

- data has not been reported in the paper. 
revealed their upregulation in the hypoxia high-risk group (163). On the other hand, the HCC hypoxia low-risk group showed increased immune score, based on ESTIMATE (Estimation of STromal and Immune cells in MAlignant Tumor tissues using Expression data) (187), which infers the stromal and immune cell fractions in a tumor sample using gene expression signatures. The increased immune score indicates higher infiltration of immune cells in regions of lower hypoxia (164). These findings are in line with reports from hypoxia-immune signatures, which include a mixture of hypoxia- and immune-related genes, and have similarly associated the presence of tumor hypoxia with an immunosuppressed state (188-190).

Prospective studies are required to validate the clinical impact of these signatures. Nonetheless, they provide proof of concept for the application of signatures to embody distinct facets of the TME including hypoxia and immune activation and predict patients' clinical outcomes. These features can be harnessed in the context of vascular normalization wherein signatures could act as indirect indicators for the reversal of an abnormal vasculature. Alternatively, the signatures could play a role in predicting treatment trajectories when vascular normalization approaches are used in combination with other treatment modalities, like immunotherapy. This concept has recently been applied to generate a mathematical model to predict impact of vascular normalization on the success of immunotherapy (9). Considering markers of vascular integrity and mechanical tumor properties (9) and advancing combinational approaches that integrate TME parameters, should realize the translational impact of vascular normalization strategies.

\section{DISCUSSION}

Immunotherapeutic strategies are witnessing an explosion and constitute a disruptive revolution in cancer treatment thanks to their significant efficacy and lasting benefits (191). However, despite the significant progress, we are currently facing a wide range of challenges. There is still a need for more effective treatments to maximize cancer patient survival rates. A challenge related to the hostility and complexity of the tumor microenvironment remains to be further elucidated to position immunotherapy as a transformative and the most used approach for the treatment of cancer. Clearly a conflict between the tumor system and an unfavorable tumor microenvironment able to neutralize or paralyze the immune system of the host exists. Several TME associated cellular and metabolic factors contribute to the failures in cancer therapies, including immunotherapy (192). In this regard, hypoxia, which is a hallmark of solid tumors, plays a crucial role in tumor promotion and immune escape by conferring tumor resistance, immunosuppression, and tumor heterogeneity. Hypoxia in solid tumors also promotes angiogenesis that is required for tumor progression as tumor cell growth frequently outstrips the supply of oxygen and nutrients. The HIF-1 mediated transcriptional response to hypoxia is cell-type specific and involves an orchestrated expression of angiogenic growth factors by various cell types within the hypoxic tissue in a temporally and spatially regulated manner. Several angiogenic factors including in particular VEGF-A bind to their cognate receptors on target cells within the stroma and regulate their behavior and reactivity to the immune cells. They also participate to the recruitment of immune cells, forming the immune infiltrate to fight the tumor cells but which, under the influence of the hypoxia-dependent composition of the TME, are changing their phenotype or are selected to help the tumor cells development and dissemination (193). Angiogenesis and its functional state, together with the TME operate in a crosstalk to control the possibility of treatments and to rule the type and quality of the immune response. It appears thus, as a necessity to focus on the search for means to control it. Normalization is indeed a concept that has, and will, change the combined treatment approaches. To get a better understanding of the means that one can apply to patients, the large scale gene analysis taking into account hypoxia appears necessary under the conditions that it is combined with the immune-related interpretation of the data and pooling the various new and old parameters helping to understand the TME vs tumor cells reactions (194).

At such point the biological and biochemical implications of the angiogenesis-based mechanisms and the possibility they offer to control drug accessibility to tumor cells on the one hand as well as the TME composition and cellular reactions on the other hand make their modulation fundamental. This opens to new roads for the immune checkpoints control. PD1/PD-L1 interactions, among immune checkpoints give an example of the huge potential provided by the angiogenesis normalization approaches as the poor effects of the treatments obtained to date imply that those strategies should be revisited in the hypoxia alleviation context (4).

\section{AUTHOR CONTRIBUTIONS}

$\mathrm{RA}, \mathrm{KB}, \mathrm{AF}, \mathrm{CK}$, and SC contributed to writing the manuscript. $\mathrm{NZ}, \mathrm{SB}$, and CS contributed to revising the manuscript. All authors contributed to the article and approved the submitted version.

\section{FUNDING}

CK and AF were supported by Ministry of Defense grant Kosciuszko I no 579/2016/DA. CK was supported by National Scientific Center grants no OPUS2016/23/B/NZ6/02542 and OPUS2016/23/B/NZ1/03211. KB was supported by Military Institute of Medicine intramural grant no 1/8910 (414).

\section{ACKNOWLEDGMENTS}

RA, SC, and NZ would like to acknowledge the support received from Gulf Medical University and the Sheikh Hamdan Bin Rashid Al Maktoum Award for Medical Sciences (MRG-266/ 2017-2018). 


\section{REFERENCES}

1. Maman S, Witz IP. A history of exploring cancer in context. Nat Rev Cancer (2018) 18(6):359-76. doi: 10.1038/s41568-018-0006-7

2. Brassart-Pasco S, Brezillon S, Brassart B, Ramont L, Oudart JB, Monboisse JC. Tumor Microenvironment: Extracellular Matrix Alterations Influence Tumor Progression. Front Oncol (2020) 10:397. doi: 10.3389/ fonc.2020.00397

3. Semenza GL. Defining the role of hypoxia-inducible factor 1 in cancer biology and therapeutics. Oncogene (2010) 29(5):625-34. doi: 10.1038/ onc.2009.441

4. Chouaib S, Noman MZ, Kosmatopoulos K, Curran MA. Hypoxic stress: obstacles and opportunities for innovative immunotherapy of cancer. Oncogene (2017) 36(4):439-45. doi: 10.1038/onc.2016.225

5. Labani-Motlagh A, Ashja-Mahdavi M, Loskog A. The Tumor Microenvironment: A Milieu Hindering and Obstructing Antitumor Immune Responses. Front Immunol (2020) 11:940. doi: 10.3389/ fimmu.2020.00940

6. Noman MZ, Hasmim M, Messai Y, Terry S, Kieda C, Janji B, et al. Hypoxia: a key player in antitumor immune response. A Review in the Theme: Cellular Responses to Hypoxia. Am J Physiol Cell Physiol (2015) 309(9): C569-79. doi: 10.1152/ajpcell.00207.2015

7. El Alaoui-Lasmaili K, Faivre B. Antiangiogenic therapy: Markers of response, "normalization" and resistance. Crit Rev Oncol Hematol (2018) 128:118-29. doi: 10.1016/j.critrevonc.2018.06.001

8. Goel S, Duda DG, Xu L, Munn LL, Boucher Y, Fukumura D, et al. Normalization of the vasculature for treatment of cancer and other diseases. Physiol Rev (2011) 91(3):1071-121. doi: 10.1152/physrev. 00038.2010

9. Mpekris F, Voutouri C, Baish JW, Duda DG, Munn LL, Stylianopoulos T, et al. Combining microenvironment normalization strategies to improve cancer immunotherapy. Proc Natl Acad Sci USA (2020) 117(7):3728-37. doi: 10.1073/pnas.1919764117

10. Goel S, Fukumura D, Jain RK. Normalization of the tumor vasculature through oncogenic inhibition: an emerging paradigm in tumor biology. Proc Natl Acad Sci U S A (2012) 109(20):E1214. doi: 10.1073/pnas.1203794109

11. Pitt JM, Marabelle A, Eggermont A, Soria JC, Kroemer G, Zitvogel L. Targeting the tumor microenvironment: removing obstruction to anticancer immune responses and immunotherapy. Ann Oncol (2016) 27(8):1482-92. doi: 10.1093/annonc/mdw168

12. Kieda C, El Hafny-Rahbi B, Collet G, Lamerant-Fayel N, Grillon C, Guichard A, et al. Stable tumor vessel normalization with $\mathrm{pO}_{2}$ increase and endothelial PTEN activation by inositol trispyrophosphate brings novel tumor treatment. J Mol Med (Berl) (2013) 91(7):883-99. doi: 10.1007/ s00109-013-0992-6

13. Kieda C. THE TUMOR SUPPRESSOR PTEN IN CONTROL OF THE TUMOR MICROENVIRONMENT, HYPOXIA-DEPENDENT ANGIOGENESIS AND TUMOR IMMUNOSUPPRESSION. Rev Roumaine Chimie (2016) 61(89):647-55.

14. Serra H, Chivite I, Angulo-Urarte A, Soler A, Sutherland JD, ArruabarrenaAristorena A, et al. PTEN mediates Notch-dependent stalk cell arrest in angiogenesis. Nat Commun (2015) 6:7935. doi: 10.1038/ncomms8935

15. Harris BH, Barberis A, West CM, Buffa FM. Gene Expression Signatures as Biomarkers of Tumour Hypoxia. Clin Oncol (R Coll Radiol) (2015) 27 (10):547-60. doi: 10.1016/j.clon.2015.07.004

16. Yang L, West CM. Hypoxia gene expression signatures as predictive biomarkers for personalising radiotherapy. Br J Radiol (2019) 92 (1093):20180036. doi: 10.1259/bjr.20180036

17. Tharmalingham $\mathrm{H}$, Hoskin $\mathrm{P}$. Clinical trials targeting hypoxia. Br J Radiol (2019) 92(1093):20170966. doi: 10.1259/bjr.20170966

18. Abou Khouzam R, Goutham HV, Zaarour RF, Chamseddine AN, Francis A, Buart $\mathrm{S}$, et al. Integrating tumor hypoxic stress in novel and more adaptable strategies for cancer immunotherapy. Semin Cancer Biol (2020) 65:140-54. doi: 10.1016/j.semcancer.2020.01.003

19. Balkwill FR, Capasso M, Hagemann T. The tumor microenvironment at a glance. J Cell Sci (2012) 125(Pt 23):5591-6. doi: 10.1242/jcs.116392

20. Kalluri R. The biology and function of fibroblasts in cancer. Nat Rev Cancer (2016) 16(9):582-98. doi: 10.1038/nrc.2016.73
21. Martin M, Wei H, Lu T. Targeting microenvironment in cancer therapeutics. Oncotarget (2016) 7(32):52575-83. doi: 10.18632/oncotarget.9824

22. Santi A, Kugeratski FG, Zanivan S. Cancer Associated Fibroblasts: The Architects of Stroma Remodeling. Proteomics (2018) 18(5-6):e1700167. doi: 10.1002/pmic. 201700167

23. Quail DF, Joyce JA. Microenvironmental regulation of tumor progression and metastasis. Nat Med (2013) 19(11):1423-37. doi: 10.1038/nm.3394

24. Haibe Y, Kreidieh M, El Hajj H, Khalifeh I, Mukherji D, Temraz S, et al. Resistance Mechanisms to Anti-angiogenic Therapies in Cancer. Front Oncol (2020) 10:221. doi: 10.3389/fonc.2020.00221

25. Jain RK. Normalizing tumor microenvironment to treat cancer: bench to bedside to biomarkers. J Clin Oncol (2013) 31(17):2205-18. doi: 10.1200/ JCO.2012.46.3653

26. Galon J, Bruni D. Tumor Immunology and Tumor Evolution: Intertwined Histories. Immunity (2020) 52(1):55-81. doi: 10.1016/j.immuni. 2019.12.018

27. Cassim S, Pouyssegur J. Tumor Microenvironment: A Metabolic Player that Shapes the Immune Response. Int J Mol Sci (2019) 21(1):157. doi: 10.3390/ ijms21010157

28. Lunt SJ, Chaudary N, Hill RP. The tumor microenvironment and metastatic disease. Clin Exp Metastasis (2009) 26(1):19-34. doi: 10.1007/s10585-0089182-2

29. Vaupel P, Mayer A. Hypoxia in cancer: significance and impact on clinical outcome. Cancer Metastasis Rev (2007) 26(2):225-39. doi: 10.1007/s10555007-9055-1

30. Lv X, Li J, Zhang C, Hu T, Li S, He S, et al. The role of hypoxia-inducible factors in tumor angiogenesis and cell metabolism. Genes Dis (2017) 4 (1):19-24. doi: 10.1016/j.gendis.2016.11.003

31. Vander Heiden MG, Cantley LC, Thompson CB. Understanding the Warburg effect: the metabolic requirements of cell proliferation. Science (2009) 324(5930):1029-33. doi: 10.1126/science.1160809

32. Qiu GZ, Jin MZ, Dai JX, Sun W, Feng JH, Jin WL. Reprogramming of the Tumor in the Hypoxic Niche: The Emerging Concept and Associated Therapeutic Strategies. Trends Pharmacol Sci (2017) 38(8):669-86. doi: 10.1016/j.tips.2017.05.002

33. Chiche J, Ilc K, Laferriere J, Trottier E, Dayan F, Mazure NM, et al. Hypoxiainducible carbonic anhydrase IX and XII promote tumor cell growth by counteracting acidosis through the regulation of the intracellular $\mathrm{pH}$. Cancer Res (2009) 69(1):358-68. doi: 10.1158/0008-5472.CAN-08-2470

34. Keith B, Johnson RS, Simon MC. HIF1alpha and HIF2alpha: sibling rivalry in hypoxic tumour growth and progression. Nat Rev Cancer (2011) 12(1):922. doi: $10.1038 / \operatorname{nrc} 3183$

35. Schito L, Semenza GL. Hypoxia-Inducible Factors: Master Regulators of Cancer Progression. Trends Cancer (2016) 2(12):758-70. doi: 10.1016/ j.trecan.2016.10.016

36. Lugano R, Ramachandran M, Dimberg A. Tumor angiogenesis: causes, consequences, challenges and opportunities. Cell Mol Life Sci (2020) 77 (9):1745-70. doi: 10.1007/s00018-019-03351-7

37. Liao D, Johnson RS. Hypoxia: a key regulator of angiogenesis in cancer. Cancer Metastasis Rev (2007) 26(2):281-90. doi: 10.1007/s10555-007-9066-y

38. Schito L. Hypoxia-Dependent Angiogenesis and Lymphangiogenesis in Cancer. Adv Exp Med Biol (2019) 1136:71-85. doi: 10.1007/978-3-03012734-3 5

39. Ferrara N, Gerber HP, LeCouter J. The biology of VEGF and its receptors. Nat Med (2003) 9(6):669-76. doi: 10.1038/nm0603-669

40. Vaish V, Sanyal SN. Role of Sulindac and Celecoxib in the regulation of angiogenesis during the early neoplasm of colon: exploring PI3-K/PTEN/ Akt pathway to the canonical Wnt/beta-catenin signaling. BioMed Pharmacother (2012) 66(5):354-67. doi: 10.1016/j.biopha.2012.01.004

41. Lamalice L, Le Boeuf F, Huot J. Endothelial cell migration during angiogensesis. Circ Res (2007) 100(6):782-94. doi: 10.1161/01.RES.0000 259593.07661.1e

42. van Hinsbergh VW, Koolwijk P. Endothelial sprouting and angiogenesis: matrix metalloproteinases in the lead. Cardiovasc Res (2008) 78(2):203-12. doi: $10.1093 / \mathrm{cvr} / \mathrm{cvm} 102$

43. Weis SM, Cheresh DA. Pathophysiological consequences of VEGF-induced vascular permeability. Nature (2005) 437(7058):497-504. doi: 10.1038/ nature 03987 
44. Azzi S, Hebda JK, Gavard J. Vascular permeability and drug delivery in cancers. Front Oncol (2013) 3:211. doi: 10.3389/fonc.2013.00211

45. Carmeliet P, Jain RK. Principles and mechanisms of vessel normalization for cancer and other angiogenic diseases. Nat Rev Drug Discovery (2011) 10 (6):417-27. doi: 10.1038/nrd3455

46. Kibel A, Iliopoulos O, DeCaprio JA, Kaelin WG. Binding of the von HippelLindau tumor suppressor protein to Elongin B and C. Science (1995) 269 (5229):1444-6. doi: 10.1126/science.7660130

47. Zhang J, Zhang Q. VHL and Hypoxia Signaling: Beyond HIF in Cancer. Biomedicines (2018) 6(1):35. doi: 10.3390/biomedicines6010035

48. Kishida T, Stackhouse TM, Chen F, Lerman MI, Zbar B. Cellular proteins that bind the von Hippel-Lindau disease gene product: mapping of binding domains and the effect of missense mutations. Cancer Res (1995) 55(20):4544-8.

49. Salceda S, Caro J. Hypoxia-inducible factor lalpha (HIF-1alpha) protein is rapidly degraded by the ubiquitin-proteasome system under normoxic conditions. Its stabilization by hypoxia depends on redox-induced changes. J Biol Chem (1997) 272(36):22642-7. doi: 10.1074/jbc.272.36.22642

50. Tanimoto K, Makino Y, Pereira T, Poellinger L. Mechanism of regulation of the hypoxia-inducible factor-1 alpha by the von Hippel-Lindau tumor suppressor protein. EMBO J (2000) 19(16):4298-309. doi: 10.1093/emboj/ 19.16.4298

51. Maxwell PH, Wiesener MS, Chang GW, Clifford SC, Vaux EC, Cockman ME, et al. The tumour suppressor protein VHL targets hypoxia-inducible factors for oxygen-dependent proteolysis. Nature (1999) 399(6733):271-5. doi: $10.1038 / 20459$

52. Cowey CL, Rathmell WK. VHL gene mutations in renal cell carcinoma: role as a biomarker of disease outcome and drug efficacy. Curr Oncol Rep (2009) 11(2):94-101. doi: 10.1007/s11912-009-0015-5

53. Rathmell WK, Chen S. VHL inactivation in renal cell carcinoma: implications for diagnosis, prognosis and treatment. Expert Rev Anticancer Ther (2008) 8(1):63-73. doi: 10.1586/14737140.8.1.63

54. Patard JJ, Rioux-Leclercq N, Masson D, Zerrouki S, Jouan F, Collet N, et al. Absence of VHL gene alteration and high VEGF expression are associated with tumour aggressiveness and poor survival of renal-cell carcinoma. $\mathrm{Br} \mathrm{J}$ Cancer (2009) 101(8):1417-24. doi: 10.1038/sj.bjc.6605298

55. Wierzbicki PM, Klacz J, Kotulak-Chrzaszcz A, Wronska A, Stanislawowski M, Rybarczyk A, et al. Prognostic significance of VHL, HIF1A, HIF2A, VEGFA and p53 expression in patients with clear-cell renal cell carcinoma treated with sunitinib as first-line treatment. Int J Oncol (2019) 55(2):371-90. doi: 10.3892/ ijo.2019.4830

56. Brodaczewska KK, Szczylik C, Kieda C. Immune consequences of antiangiogenic therapyin renal cell carcinoma. Contemp Oncol (Pozn) (2018) 22 (1A):14-22. doi: 10.5114/wo.2018.73878

57. Hou SQ, Ouyang M, Brandmaier A, Hao H, Shen WH. PTEN in the maintenance of genome integrity: From DNA replication to chromosome segregation. Bioessays (2017) 39(10). doi: 10.1002/bies.201700082

58. Brandmaier A, Hou SQ, Shen WH. Cell Cycle Control by PTEN. J Mol Biol (2017) 429(15):2265-77. doi: 10.1016/j.jmb.2017.06.004

59. Papa A, Wan L, Bonora M, Salmena L, Song MS, Hobbs RM, et al. Cancerassociated PTEN mutants act in a dominant-negative manner to suppress PTEN protein function. Cell (2014) 157(3):595-610. doi: 10.1016/ j.cell.2014.03.027

60. Alimonti A, Carracedo A, Clohessy JG, Trotman LC, Nardella C, Egia A, et al. Subtle variations in Pten dose determine cancer susceptibility. Nat Genet (2010) 42(5):454-8. doi: 10.1038/ng.556

61. Alimonti A. PTEN breast cancer susceptibility: a matter of dose. Ecancermedicalscience (2010) 4:192. doi: 10.3332/ecancer.2010.1924

62. Chen W, Xia P, Wang H, Tu J, Liang X, Zhang X, et al. The endothelial tipstalk cell selection and shuffling during angiogenesis. J Cell Commun Signal (2019) 13(3):291-301. doi: 10.1007/s12079-019-00511-z

63. Dang EV, Barbi J, Yang HY, Jinasena D, Yu H, Zheng Y, et al. Control of T (H)17/T(reg) balance by hypoxia-inducible factor 1. Cell (2011) 146(5):77284. doi: 10.1016/j.cell.2011.07.033

64. Noman MZ, Desantis G, Janji B, Hasmim M, Karray S, Dessen P, et al. PDL1 is a novel direct target of HIF-1alpha, and its blockade under hypoxia enhanced MDSC-mediated T cell activation. J Exp Med (2014) 211(5):78190. doi: $10.1084 /$ jem. 20131916
65. Corzo CA, Condamine T, Lu L, Cotter MJ, Youn JI, Cheng P, et al. HIF-1 $\alpha$ regulates function and differentiation of myeloid-derived suppressor cells in the tumor microenvironment. J Exp Med (2010) 207(11):2439-53. doi: 10.1084/jem.20100587

66. Chaturvedi P, Gilkes DM, Takano N, Semenza GL. Hypoxia-inducible factor-dependent signaling between triple-negative breast cancer cells and mesenchymal stem cells promotes macrophage recruitment. Proc Natl Acad Sci U S A (2014) 111(20):E2120-9. doi: 10.1073/pnas.1406655111

67. Werno C, Menrad H, Weigert A, Dehne N, Goerdt S, Schledzewski K, et al. Knockout of HIF-1 $\alpha$ in tumor-associated macrophages enhances M2 polarization and attenuates their pro-angiogenic responses. Carcinogenesis (2010) 31(10):1863-72. doi: 10.1093/carcin/bgq088

68. White JR, Harris RA, Lee SR, Craigon MH, Binley K, Price T, et al. Genetic amplification of the transcriptional response to hypoxia as a novel means of identifying regulators of angiogenesis. Genomics (2004) 83(1):1-8. doi 10.1016/S0888-7543(03)00215-5

69. Gabrilovich DI, Chen HL, Girgis KR, Cunningham HT, Meny GM, Nadaf S, et al. Production of vascular endothelial growth factor by human tumors inhibits the functional maturation of dendritic cells. Nat Med (1996) 2 (10):1096-103. doi: 10.1038/nm1096-1096

70. Mancino A, Schioppa T, Larghi P, Pasqualini F, Nebuloni M, Chen IH, et al. Divergent effects of hypoxia on dendritic cell functions. Blood (2008) 112 (9):3723-34. doi: 10.1182/blood-2008-02-142091

71. Clambey ET, McNamee EN, Westrich JA, Glover LE, Campbell EL, Jedlicka P, et al. Hypoxia-inducible factor- 1 alpha-dependent induction of FoxP3 drives regulatory T-cell abundance and function during inflammatory hypoxia of the mucosa. Proc Natl Acad Sci USA (2012) 109(41):E2784-93. doi: 10.1073/ pnas. 1202366109

72. Facciabene A, Peng X, Hagemann IS, Balint K, Barchetti A, Wang LP, et al. Tumour hypoxia promotes tolerance and angiogenesis via CCL28 and T (reg) cells. Nature (2011) 475(7355):226-30. doi: 10.1038/nature10169

73. Hasmim M, Noman MZ, Messai Y, Bordereaux D, Gros G, Baud V, et al. Cutting edge: Hypoxia-induced Nanog favors the intratumoral infiltration of regulatory $\mathrm{T}$ cells and macrophages via direct regulation of TGF- $\beta 1$. J Immunol (2013) 191(12):5802-6. doi: 10.4049/jimmunol.1302140

74. Chen B, Li L, Li M, Wang X. HIF1A expression correlates with increased tumor immune and stromal signatures and aggressive phenotypes in human cancers. Cell Oncol (Dordr) (2020) 43(5):877-88. doi: 10.1007/s13402-02000534-4

75. Doedens AL, Phan AT, Stradner MH, Fujimoto JK, Nguyen JV, Yang E, et al. Hypoxia-inducible factors enhance the effector responses of CD8(+) T cells to persistent antigen. Nat Immunol (2013) 14(11):1173-82. doi: 10.1038/ ni.2714

76. Tyrakis PA, Palazon A, Macias D, Lee KL, Phan AT, Veliça P, et al. S-2hydroxyglutarate regulates CD8. Nature (2016) 540(7632):236-41. doi: 10.1038/nature20165

77. Velásquez SY, Killian D, Schulte J, Sticht C, Thiel M, Lindner HA. Short Term Hypoxia Synergizes with Interleukin 15 Priming in Driving Glycolytic Gene Transcription and Supports Human Natural Killer Cell Activities. J Biol Chem (2016) 291(25):12960-77. doi: 10.1074/jbc.M116.721753

78. Zünd G, Nelson DP, Neufeld EJ, Dzus AL, Bischoff J, Mayer JE, et al Hypoxia enhances stimulus-dependent induction of E-selectin on aortic endothelial cells. Proc Natl Acad Sci USA (1996) 93(14):7075-80. doi: 10.1073/pnas.93.14.7075

79. Liang X, Arullampalam P, Yang Z, Ming XF. Hypoxia Enhances Endothelial Intercellular Adhesion Molecule 1 Protein Level Through Upregulation of Arginase Type II and Mitochondrial Oxidative Stress. Front Physiol (2019) 10:1003. doi: 10.3389/fphys.2019.01003

80. Antonova OA, Loktionova SA, Romanov YA, Shustova ON, Khachikian MV, Mazurov AV. Activation and damage of endothelial cells upon hypoxia/reoxygenation. Effect of extracellular pH. Biochem (Mosc) (2009) 74(6):605-12. doi: 10.1134/S0006297909060030

81. Bellone M, Calcinotto A. Ways to enhance lymphocyte trafficking into tumors and fitness of tumor infiltrating lymphocytes. Front Oncol (2013) 3:231. doi: 10.3389 /fonc. 2013.00231

82. Flati V, Pastore LI, Griffioen AW, Satijn S, Toniato E, D'Alimonte I, et al. Endothelial cell anergy is mediated by bFGF through the sustained activation 
of p38-MAPK and NF-kappaB inhibition. Int J Immunopathol Pharmacol (2006) 19(4):761-73. doi: 10.1177/039463200601900406

83. Dirkx AE, Oude Egbrink MG, Kuijpers MJ, van der Niet ST, Heijnen VV, Bouma-ter Steege JC, et al. Tumor angiogenesis modulates leukocyte-vessel wall interactions in vivo by reducing endothelial adhesion molecule expression. Cancer Res (2003) 63(9):2322-9.

84. Griffioen AW, Damen CA, Blijham GH, Groenewegen G. Tumor angiogenesis is accompanied by a decreased inflammatory response of tumor-associated endothelium. Blood (1996) 88(2):667-73. doi: 10.1182/ blood.V88.2.667.bloodjournal882667

85. Tabruyn SP, Sabatel C, Nguyen NQ, Verhaeghe C, Castermans K, Malvaux L, et al. The angiostatic $16 \mathrm{~K}$ human prolactin overcomes endothelial cell anergy and promotes leukocyte infiltration via nuclear factor-kappaB activation. $\mathrm{Mol}$ Endocrinol (2007) 21(6):1422-9. doi: 10.1210/me.2007-0021

86. Piali L, Fichtel A, Terpe HJ, Imhof BA, Gisler RH. Endothelial vascular cell adhesion molecule 1 expression is suppressed by melanoma and carcinoma. J Exp Med (1995) 181(2):811-6. doi: 10.1084/jem.181.2.811

87. Bessa X, Elizalde JI, Mitjans F, Piñol V, Miquel R, Panés J, et al. Leukocyte recruitment in colon cancer: role of cell adhesion molecules, nitric oxide, and transforming growth factor beta1. Gastroenterology (2002) 122(4):1122-32. doi: 10.1053/gast.2002.32369

88. Dirkx AE, oude Egbrink MG, Castermans K, van der Schaft DW, Thijssen VL, Dings RP, et al. Anti-angiogenesis therapy can overcome endothelial cell anergy and promote leukocyte-endothelium interactions and infiltration in tumors. FASEB J (2006) 20(6):621-30. doi: 10.1096/fj.05-4493com

89. Hellebrekers DM, Castermans K, Viré E, Dings RP, Hoebers NT, Mayo KH, et al. Epigenetic regulation of tumor endothelial cell anergy: silencing of intercellular adhesion molecule-1 by histone modifications. Cancer Res (2006) 66(22):10770-7. doi: 10.1158/0008-5472.CAN-06-1609

90. Riegler J, Gill H, Ogasawara A, Hedehus M, Javinal V, Oeh J, et al. VCAM-1 Density and Tumor Perfusion Predict T-cell Infiltration and Treatment Response in Preclinical Models. Neoplasia (2019) 21(10):1036-50. doi: 10.1016/j.neo.2019.08.003

91. van Hooren L, Georganaki M, Huang H, Mangsbo SM, Dimberg A. Sunitinib enhances the antitumor responses of agonistic CD40-antibody by reducing MDSCs and synergistically improving endothelial activation and T-cell recruitment. Oncotarget (2016) 7(31):50277-89. doi: 10.18632/oncotarget.10364

92. Walshe TE, Dole VS, Maharaj AS, Patten IS, Wagner DD, D'Amore PA. Inhibition of VEGF or TGF-\{beta\} signaling activates endothelium and increases leukocyte rolling. Arterioscler Thromb Vasc Biol (2009) 29 (8):1185-92. doi: 10.1161/ATVBAHA.109.186742

93. Buckanovich RJ, Facciabene A, Kim S, Benencia F, Sasaroli D, Balint K, et al. Endothelin B receptor mediates the endothelial barrier to $\mathrm{T}$ cell homing to tumors and disables immune therapy. Nat Med (2008) 14(1):28-36. doi: $10.1038 / \mathrm{nm} 1699$

94. Taguchi K, Onoe T, Yoshida T, Yamashita Y, Tanaka Y, Ohdan H. Tumor Endothelial Cell-Mediated Antigen-Specific T-cell Suppression via the PD1/PD-L1 Pathway. Mol Cancer Res (2020) 18(9):1427-40. doi: 10.1158/15417786.MCR-19-0897

95. Rodig N, Ryan T, Allen JA, Pang H, Grabie N, Chernova T, et al. Endothelial expression of PD-L1 and PD-L2 down-regulates CD8+ T cell activation and cytolysis. Eur J Immunol (2003) 33(11):3117-26. doi: 10.1002/eji.200324270

96. Lim WC, Olding M, Healy E, Millar TM. Human Endothelial Cells Modulate CD4(+) T Cell Populations and Enhance Regulatory T Cell Suppressive Capacity. Front Immunol (2018) 9:565. doi: 10.3389/fimmu.2018.00565

97. Chen WJ, Hu XF, Yan M, Zhang WY, Mao XB, Shu YW. Human umbilical vein endothelial cells promote the inhibitory activation of CD4(+)CD25(+) Foxp3(+) regulatory T cells via PD-L1. Atherosclerosis (2016) 244:108-12. doi: 10.1016/j.atherosclerosis.2015.11.002

98. Schmittnaegel M, Rigamonti N, Kadioglu E, Cassará A, Wyser Rmili C, Kiialainen A, et al. Dual angiopoietin-2 and VEGFA inhibition elicits antitumor immunity that is enhanced by PD-1 checkpoint blockade. Sci Transl Med (2017) 9(385):eaak9670. doi: 10.1126/scitranslmed.aak9670

99. Liu S, Qin T, Liu Z, Wang J, Jia Y, Feng Y, et al. anlotinib alters tumor immune microenvironment by downregulating PD-L1 expression on vascular endothelial cells. Cell Death Dis (2020) 11(5):309. doi: 10.1038/ s41419-020-2511-3
100. Matejuk A, Collet G, Nadim M, Grillon C, Kieda C. MicroRNAs and tumor vasculature normalization: Impact on anti-tumor immune response. Archivum Immunologiae Therapiae Experimentalis (2013) 61(4):285-99. doi: 10.1007/s00005-013-0231-4

101. Qin S, Li A, Yi M, Yu S, Zhang M, Wu K. Recent advances on antiangiogenesis receptor tyrosine kinase inhibitors in cancer therapy. J Hematol Oncol (2019) 12(1):27. doi: 10.1186/s13045-019-0718-5

102. Gotink KJ, Verheul HMW. Anti-angiogenic tyrosine kinase inhibitors: What is their mechanism of action? Angiogenesis (2010) 13(1):1-14. doi: 10.1007/ s10456-009-9160-6

103. Batchelor TT, Gerstner ER, Emblem KE, Duda DG, Kalpathy-Cramer J, Snuderl M, et al. Improved tumor oxygenation and survival in glioblastoma patients who show increased blood perfusion after cediranib and chemoradiation. Proc Natl Acad Sci United States America (2013) 110 (47):19059-64. doi: 10.1073/pnas.1318022110

104. Huynh H, Lee LY, Goh KY, Ong R, Hao HX, Huang A, et al. Infigratinib Mediates Vascular Normalization, Impairs Metastasis, and Improves Chemotherapy in Hepatocellular Carcinoma. Hepatology (2019) 69 (3):943-58. doi: 10.1002/hep.30481

105. Tolaney SM, Boucher Y, Duda DG, Martin JD, Seano G, Ancukiewicz M, et al. Role of vascular density and normalization in response to neoadjuvant bevacizumab and chemotherapy in breast cancer patients. Proc Natl Acad Sci U S A (2015) 112(46):14325-30. doi: 10.1073/pnas.1518808112

106. Franco M, Roswall P, Cortez E, Hanahan D, Pietras K. Pericytes promote endothelial cell survival through induction of autocrine VEGF-A signaling and Bcl-w expression. Blood (2011) 118(10):2906-17. doi: 10.1182/blood2011-01-331694

107. Verstraete M, Debucquoy A, Dekervel J, Van Pelt J, Verslype C, Devos E, et al. Combining bevacizumab and chemoradiation in rectal cancer. Translational results of the AXEBeam trial. Br J Cancer (2015) 112 (8):1314-25. doi: 10.1038/bjc.2015.93

108. Casanovas O, Hicklin DJ, Bergers G, Hanahan D. Drug resistance by evasion of antiangiogenic targeting of VEGF signaling in late-stage pancreatic islet tumors. Cancer Cell (2005) 8(4):299-309. doi: 10.1016/ j.ccr.2005.09.005

109. Collet G, Skrzypek K, Grillon C, Matejuk A, El Hafni-Rahbi B, Lamerant Fayel N, et al. Hypoxia control to normalize pathologic angiogenesis: Potential role for endothelial precursor cells and miRNAs regulation. Vasc Pharmacol (2012) 56(5-6):252-61. doi: 10.1016/j.vph.2012.03.001

110. Collet G, Lamerant-Fayel N, Tertil M, El Hafny-Rahbi B, Stepniewski J, Guichard A, et al. Hypoxia-regulated overexpression of soluble VEGFR2 controls angiogenesis and inhibits tumor growth. Mol Cancer Ther (2014) 13 (1):165-78. doi: 10.1158/1535-7163.MCT-13-0637

111. Mazzone M, Dettori D, Oliveira RLD, Schmidt T, Jonckx B, Tian Y-M, et al. Heterozygous Deficiency of PHD2 Restores Tumor Oxygenation and Inhibits Metastasis via Endothelial Normalization. Cell (2014) 136: (5):839-51. doi: 10.1016/j.cell.2009.01.020

112. Sakashita M, Tanaka T, Nangaku M. Hypoxia-Inducible Factor-Prolyl Hydroxylase Domain Inhibitors to Treat Anemia in Chronic Kidney Disease. Contributions to Nephrol (2019) 198:112-23. doi: 10.1159/ 000496531

113. Nishide S, Uchida J, Matsunaga S, Tokudome K, Yamaguchi T, Kabei K, et al. Prolyl-hydroxylase inhibitors reconstitute tumor blood vessels in mice. J Pharmacol Sci (2020) 143(2):122-6. doi: 10.1016/j.jphs.2020.02.010

114. Duarte CD, Greferath R, Nicolau C, Lehn JM. myo-Inositol trispyrophosphate: a novel allosteric effector of hemoglobin with high permeation selectivity across the red blood cell plasma membrane. Chembiochem (2010) 11(18):2543-8. doi: 10.1002/cbic.201000499

115. Kieda C, Paprocka M, Krawczenko A, Załecki P, Dupuis P, Monsigny M, et al. New human microvascular endothelial cell lines with specific adhesion molecules phenotypes. Endothelium (2002) 9(4):247-61. doi: 10.1080/ 10623320214736

116. Kieda C, Greferath R, Da Silva CC, Fylaktakidou KC, Lehn JM, Nicolau C. Suppression of hypoxia-induced HIF- $1 \alpha$ and of angiogenesis in endothelial cells by myo-inositol trispyrophosphate-treated erythrocytes. Proc Natl Acad Sci U S A (2006) 103(42):15576-81. doi: 10.1073/pnas. 0607109103 
117. Paprocka M, Krawczenko A, Dus D, Kantor A, Carreau A, Grillon C, et al. CD133 positive progenitor endothelial cell lines from human cord blood. Cytometry Part A (2011) 79 A(8):594-602. doi: 10.1002/ cyto.a.21092

118. Collet G, Szade K, Nowak W, Klimkiewicz K, El Hafny-Rahbi B, Szczepanek K, et al. Endothelial precursor cell-based therapy to target the pathologic angiogenesis and compensate tumor hypoxia. Cancer Lett (2016) 370(2):34557. doi: 10.1016/j.canlet.2015.11.008

119. Thébaud B. Stem cell-based therapies in neonatology: A new hope. Archives of Disease in Childhood: Fetal and Neonatal Edition. Arch Dis Child Fetal Neonatal Ed (2018) 103:(6):F583-F8. doi: 10.1136/ archdischild-2017-314451

120. Collet G, Grillon C, Nadim M, Kieda C. Trojan horse at cellular level for tumor gene therapies. Gene (2013) 525(2):208-16. doi: 10.1016/ j.gene.2013.03.057

121. Lavergne M, Vanneaux V, Delmau C, Gluckman E, Rodde-Astier I, Larghero J, et al. Cord blood-circulating endothelial progenitors for treatment of vascular diseases. Cell Proliferation (2011) 44(SUPPL. 1):44-7. doi: 10.1111/j.13652184.2010.00722.x

122. Dudek AZ. Endothelial lineage cell as a vehicle for systemic delivery of cancer gene therapy. Trans Res (2010) 156(3):136-46. doi: 10.1016/j.trsl.2010.07.003

123. Laurenzana A, Margheri F, Chillà A, Biagioni A, Margheri G, Calorini L, et al. Endothelial Progenitor Cells as Shuttle of Anticancer Agents. Hum Gene Ther (2016) 27(10):784-91. doi: 10.1089/hum.2016.066

124. Park JS, Kim IK, Han S, Park I, Kim C, Bae J, et al. Normalization of Tumor Vessels by Tie2 Activation and Ang2 Inhibition Enhances Drug Delivery and Produces a Favorable Tumor Microenvironment. Cancer Cell (2016) 30 (6):953-67. doi: 10.1016/j.ccell.2016.10.018

125. Hamada K, Sasaki T, Koni PA, Natsui M, Kishimoto H, Sasaki J, et al. The PTEN/PI3K pathway governs normal vascular development and tumor angiogenesis. Genes Dev (2005) 19(17):2054-65. doi: 10.1101/gad.1308805

126. Su JD, Mayo LD, Donner DB, Durden DL. PTEN and phosphatidylinositol 3'-kinase inhibitors up-regulate p53 and block tumor-induced angiogenesis: evidence for an effect on the tumor and endothelial compartment. Cancer Res (2003) 63(13):3585-92.

127. Morotti M, Dass PH, Harris AL, Lord S. Pharmacodynamic and Pharmacokinetic Markers For Anti-angiogenic Cancer Therapy: Implications for Dosing and Selection of Patients. Eur J Drug Metab Pharmacokinet (2018) 43(2):137-53. doi: 10.1007/s13318-017-0442-x

128. Li W, Quan YY, Li Y, Lu L, Cui M. Monitoring of tumor vascular normalization: the key points from basic research to clinical application. Cancer Manag Res (2018) 10:4163-72. doi: 10.2147/CMAR.S174712

129. Ivanov S, Liao SY, Ivanova A, Danilkovitch-Miagkova A, Tarasova N, Weirich G, et al. Expression of hypoxia-inducible cell-surface transmembrane carbonic anhydrases in human cancer. Am J Pathol (2001) 158(3):905-19. doi: 10.1016/S0002-9440(10)64038-2

130. Bonnitcha P, Grieve S, Figtree G. Clinical imaging of hypoxia: Current status and future directions. Free Radic Biol Med (2018) 126:296-312. doi: 10.1016/ j.freeradbiomed.2018.08.019

131. Aguilera KY, Brekken RA. Hypoxia Studies with Pimonidazole in vivo. Bio Protoc (2014) 4(19):e1254. doi: 10.21769/BioProtoc.1254

132. Rivera BK, Naidu SK, Subramanian K, Joseph M, Hou H, Khan N, et al. Realtime, in vivo determination of dynamic changes in lung and heart tissue oxygenation using EPR oximetry. Adv Exp Med Biol (2014) 812:81-6. doi: 10.1007/978-1-4939-0620-8_11

133. Swartz HM, Hou H, Khan N, Jarvis LA, Chen EY, Williams BB, et al. Advances in probes and methods for clinical EPR oximetry. Adv Exp Med Biol (2014) 812:73-9. doi: 10.1007/978-1-4939-0620-8_10

134. Khramtsov VV. In Vivo Molecular Electron Paramagnetic Resonance-Based Spectroscopy and Imaging of Tumor Microenvironment and Redox Using Functional Paramagnetic Probes. Antioxid Redox Signal (2018) 28(15):136577. doi: 10.1089 /ars.2017.7329

135. Sersa G, Krzic M, Sentjurc M, Ivanusa T, Beravs K, Kotnik V, et al. Reduced blood flow and oxygenation in SA-1 tumours after electrochemotherapy with cisplatin. Br J Cancer (2002) 87(9):1047-54. doi: 10.1038/sj.bjc.6600606

136. Jordan BF, Beghein N, Aubry M, Gregoire V, Gallez B. Potentiation of radiation-induced regrowth delay by isosorbide dinitrate in FSaII murine tumors. Int J Cancer (2003) 103(1):138-41. doi: 10.1002/ijc.10786
137. Cron GO, Beghein N, Crokart N, Chavee E, Bernard S, Vynckier S, et al. Changes in the tumor microenvironment during low-dose-rate permanent seed implantation iodine-125 brachytherapy. Int J Radiat Oncol Biol Phys (2005) 63(4):1245-51. doi: 10.1016/j.ijrobp.2005.07.971

138. Mupparaju S, Hou H, Lariviere JP, Swartz HM, Khan N. Tumor pO(2) as a surrogate marker to identify therapeutic window during metronomic chemotherapy of 9L gliomas. Adv Exp Med Biol (2011) 701:107-13. doi: 10.1007/978-1-4419-7756-4_15

139. Matsumoto S, Batra S, Saito K, Yasui H, Choudhuri R, Gadisetti C, et al. Antiangiogenic agent sunitinib transiently increases tumor oxygenation and suppresses cycling hypoxia. Cancer Res (2011) 71(20):6350-9. doi: 10.1158/ 0008-5472.CAN-11-2025

140. Kishimoto S, Matsumoto KI, Saito K, Enomoto A, Matsumoto S, Mitchell JB, et al. Pulsed Electron Paramagnetic Resonance Imaging: Applications in the Studies of Tumor Physiology. Antioxid Redox Signal (2018) 28(15):1378-93. doi: 10.1089/ars.2017.7391

141. Khan N, Hou H, Eskey CJ, Moodie K, Gohain S, Du G, et al. Deep-tissue oxygen monitoring in the brain of rabbits for stroke research. Stroke (2015) 46(3):e62-6. doi: 10.1161/STROKEAHA.114.007324

142. Flood AB, Wood VA, Swartz HM. Using India Ink as a Sensor for Oximetry: Evidence of its Safety as a Medical Device. Adv Exp Med Biol (2017) 977:297312. doi: 10.1007/978-3-319-55231-6 40

143. Hou H, Khan N, Gohain S, Kuppusamy ML, Kuppusamy P. Pre-clinical evaluation of OxyChip for long-term EPR oximetry. BioMed Microdevices (2018) 20(2):29. doi: 10.1007/s10544-018-0272-x

144. Flood AB, Schaner PE, Vaupel P, Williams BB, Gallez B, Chen EY, et al. Clinical and Statistical Considerations when Assessing Oxygen Levels in Tumors: Illustrative Results from Clinical EPR Oximetry Studies. Adv Exp Med Biol (2020) 1232:155-68. doi: 10.1007/978-3-030-34461-0_20

145. Epel B, Redler G, Tormyshev V, Halpern HJ. Towards Human Oxygen Images with Electron Paramagnetic Resonance Imaging. Adv Exp Med Biol (2016) 876:363-9. doi: 10.1007/978-1-4939-3023-4_45

146. Gertsenshteyn I, Giurcanu M, Vaupel P, Halpern H. Biological validation of electron paramagnetic resonance (EPR) image oxygen thresholds in tissue. J Physiol (2020) 7:10. doi: 10.1113/JP278816

147. O'Connor JPB, Robinson SP, Waterton JC. Imaging tumour hypoxia with oxygen-enhanced MRI and BOLD MRI. Br J Radiol (2019) 92 (1095):20180642. doi: 10.1259/bjr.20180642

148. Liang J, Cheng Q, Huang J, Ma M, Zhang D, Lei X, et al. Monitoring tumour microenvironment changes during anti-angiogenesis therapy using functional MRI. Angiogenesis (2019) 22(3):457-70. doi: 10.1007/s10456019-09670-4

149. Yopp AC, Schwartz LH, Kemeny N, Gultekin DH, Gonen M, Bamboat Z, et al. Antiangiogenic therapy for primary liver cancer: correlation of changes in dynamic contrast-enhanced magnetic resonance imaging with tissue hypoxia markers and clinical response. Ann Surg Oncol (2011) 18(8):21929. doi: 10.1245/s10434-011-1570-1

150. Wegner CS, Hauge A, Simonsen TG, Gaustad JV, Andersen LMK, Rofstad EK. DCE-MRI of Sunitinib-Induced Changes in Tumor Microvasculature and Hypoxia: A Study of Pancreatic Ductal Adenocarcinoma Xenografts. Neoplasia (2018) 20(7):734-44. doi: 10.1016/j.neo.2018.05.006

151. Hauge A, Gaustad JV, Huang R, Simonsen TG, Wegner CS, Andersen LMK, et al. DCE-MRI and Quantitative Histology Reveal Enhanced Vessel Maturation but Impaired Perfusion and Increased Hypoxia in Bevacizumab-Treated Cervical Carcinoma. Int J Radiat Oncol Biol Phys (2019) 104(3):666-76. doi: 10.1016/j.ijrobp.2019.03.002

152. Shen B, Huang T, Sun Y, Jin Z, Li XF. Revisit 18F-fluorodeoxyglucose oncology positron emission tomography: "systems molecular imaging" of glucose metabolism. Oncotarget (2017) 8(26):43536-42. doi: 10.18632/ oncotarget.16647

153. Miles KA, Williams RE. Warburg revisited: imaging tumour blood flow and metabolism. Cancer Imaging (2008) 8:81-6. doi: 10.1102/14707330.2008 .0011

154. van Elmpt W, Zegers CML, Reymen B, Even AJG, Dingemans AC, Oellers M, et al. Multiparametric imaging of patient and tumour heterogeneity in nonsmall-cell lung cancer: quantification of tumour hypoxia, metabolism and perfusion. Eur J Nucl Med Mol Imaging (2016) 43(2):240-8. doi: 10.1007/ s00259-015-3169-4 
155. Waller J, Onderdonk B, Flood A, Swartz H, Shah J, Shah A, et al. The clinical utility of imaging methods used to measure hypoxia in cervical cancer. $\mathrm{Br} \mathrm{J}$ Radiol (2020) 93(1111):20190640. doi: 10.1259/bjr.20190640

156. Hernandez-Agudo E, Mondejar T, Soto-Montenegro ML, Megias D, Mouron S, Sanchez J, et al. Monitoring vascular normalization induced by antiangiogenic treatment with (18)F-fluoromisonidazole-PET. Mol Oncol (2016) 10(5):704-18. doi: 10.1016/j.molonc.2015.12.011

157. Gerstner ER, Zhang Z, Fink JR, Muzi M, Hanna L, Greco E, et al. ACRIN 6684: Assessment of Tumor Hypoxia in Newly Diagnosed Glioblastoma Using 18F-FMISO PET and MRI. Clin Cancer Res (2016) 22(20):5079-86. doi: 10.1158/1078-0432.CCR-15-2529

158. Bekaert L, Valable S, Lechapt-Zalcman E, Ponte K, Collet S, Constans JM, et al. [18F]-FMISO PET study of hypoxia in gliomas before surgery: correlation with molecular markers of hypoxia and angiogenesis. Eur $J$ Nucl Med Mol Imaging (2017) 44(8):1383-92. doi: 10.1007/s00259-0173677-5

159. Ponte KF, Berro DH, Collet S, Constans JM, Emery E, Valable S, et al. In Vivo Relationship Between Hypoxia and Angiogenesis in Human Glioblastoma: A Multimodal Imaging Study. J Nucl Med (2017) 58 (10):1574-9. doi: 10.2967/jnumed.116.188557

160. Grkovski M, Schoder H, Lee NY, Carlin SD, Beattie BJ, Riaz N, et al. Multiparametric Imaging of Tumor Hypoxia and Perfusion with (18)FFluoromisonidazole Dynamic PET in Head and Neck Cancer. J Nucl Med (2017) 58(7):1072-80. doi: 10.2967/jnumed.116.188649

161. Carmona-Bozo JC, Manavaki R, Woitek R, Torheim T, Baxter GC, Caraco C, et al. Hypoxia and perfusion in breast cancer: simultaneous assessment using PET/MR imaging. Eur Radiol (2020) 31:333-44. doi: 10.1007/s00330-02007067-2

162. Zou YF, Rong YM, Tan YX, Xiao J, Yu ZL, Chen YF, et al. A signature of hypoxia-related factors reveals functional dysregulation and robustly predicts clinical outcomes in stage I/II colorectal cancer patients. Cancer Cell Int (2019) 19:243. doi: 10.1186/s12935-019-0964-1

163. Lin W, Wu S, Chen X, Ye Y, Weng Y, Pan Y, et al. Characterization of Hypoxia Signature to Evaluate the Tumor Immune Microenvironment and Predict Prognosis in Glioma Groups. Front Oncol (2020) 10:796. doi: 10.3389/fonc. 2020.00796

164. Deng F, Chen D, Wei X, Lu S, Luo X, He J, et al. Development and validation of a prognostic classifier based on HIF-1 signaling for hepatocellular carcinoma. Aging (Albany NY) (2020) 12(4):3431-50. doi: 10.18632/ aging.102820

165. Mo Z, Yu L, Cao Z, Hu H, Luo S, Zhang S. Identification of a HypoxiaAssociated Signature for Lung Adenocarcinoma. Front Genet (2020) 11:647. doi: 10.3389/fgene.2020.00647

166. Sun J, Zhao T, Zhao D, Qi X, Bao X, Shi R, et al. Development and validation of a hypoxia-related gene signature to predict overall survival in early-stage lung adenocarcinoma patients. Ther Adv Med Oncol (2020) 12:1758835920937904. doi: 10.1177/1758835920937904

167. Wang J, Wang Y, Xing P, Liu Q, Zhang C, Sui Y, et al. Development and validation of a hypoxia-related prognostic signature for breast cancer. Oncol Lett (2020) 20(2):1906-14. doi: 10.3892/ol.2020.11733

168. Wang Z, Gao L, Guo X, Wang Y, Ma W, Guo Y, et al. A novel hypoxic tumor microenvironment signature for predicting the survival, progression, immune responsiveness and chemoresistance of glioblastoma: a multiomic study. Aging (Albany NY) (2020) 12:17038-61. doi: 10.18632/ aging. 103626

169. Toustrup K, Sorensen BS, Nordsmark M, Busk M, Wiuf C, Alsner J, et al. Development of a hypoxia gene expression classifier with predictive impact for hypoxic modification of radiotherapy in head and neck cancer. Cancer Res (2011) 71(17):5923-31. doi: 10.1158/00085472.CAN-11-1182

170. Eustace A, Mani N, Span PN, Irlam JJ, Taylor J, Betts GN, et al. A 26-gene hypoxia signature predicts benefit from hypoxia-modifying therapy in laryngeal cancer but not bladder cancer. Clin Cancer Res (2013) 19 (17):4879-88. doi: 10.1158/1078-0432.CCR-13-0542

171. Yang L, Taylor J, Eustace A, Irlam JJ, Denley H, Hoskin PJ, et al. A Gene Signature for Selecting Benefit from Hypoxia Modification of Radiotherapy for High-Risk Bladder Cancer Patients. Clin Cancer Res (2017) 23(16):47618. doi: 10.1158/1078-0432.CCR-17-0038
172. Yang L, Roberts D, Takhar M, Erho N, Bibby BAS, Thiruthaneeswaran N, et al. Development and Validation of a 28-gene Hypoxia-related Prognostic Signature for Localized Prostate Cancer. EBioMedicine (2018) 31:182-9. doi: 10.1016/j.ebiom.2018.04.019

173. Karn T, Meissner T, Weber KE, Solbach C, Denkert C, Engels K, et al. A Small Hypoxia Signature Predicted pCR Response to Bevacizumab in the Neoadjuvant GeparQuinto Breast Cancer Trial. Clin Cancer Res (2020) 26 (8):1896-904. doi: 10.1158/1078-0432.CCR-19-1954

174. Buart S, Terry S, Noman MZ, Lanoy E, Boutros C, Fogel P, et al. Transcriptional response to hypoxic stress in melanoma and prognostic potential of GBE1 and BNIP3. Oncotarget (2017) 8(65):108786-801. doi: 10.18632/oncotarget.22150

175. Fjeldbo CS, Hompland T, Hillestad T, Aarnes EK, Günther CC, Kristensen $\mathrm{GB}$, et al. Combining imaging- and gene-based hypoxia biomarkers in cervical cancer improves prediction of chemoradiotherapy failure independent of intratumour heterogeneity. EBioMedicine (2020) 57:102841. doi: 10.1016/j.ebiom.2020.102841

176. Buffa FM, Harris AL, West CM, Miller CJ. Large meta-analysis of multiple cancers reveals a common, compact and highly prognostic hypoxia metagene. Br J Cancer (2010) 102(2):428-35. doi: 10.1038/sj.bjc.6605450

177. Fox NS, Starmans MH, Haider S, Lambin P, Boutros PC. Ensemble analyses improve signatures of tumour hypoxia and reveal inter-platform differences. BMC Bioinf (2014) 15:170. doi: 10.1186/1471-2105-15-170

178. Ye Y, Hu Q, Chen H, Liang K, Yuan Y, Xiang Y, et al. Characterization of Hypoxia-associated Molecular Features to Aid Hypoxia-Targeted Therapy. Nat Metab (2019) 1(4):431-44. doi: 10.1038/s42255-0190045-8

179. Bhandari V, Hoey C, Liu LY, Lalonde E, Ray J, Livingstone J, et al. Molecular landmarks of tumor hypoxia across cancer types. Nat Genet (2019) 51 (2):308-18. doi: 10.1038/s41588-018-0318-2

180. Bhandari V, Li CH, Bristow RG, Boutros PC. Divergent mutational processes distinguish hypoxic and normoxic tumours. Nat Commun (2020) 11(1):737. doi: $10.1038 / s 41467-019-14052-x$

181. Zhang Q, Huang R, Hu H, Yu L, Tang Q, Tao Y, et al. Integrative Analysis of Hypoxia-Associated Signature in Pan-Cancer. iScience (2020) 23(9):101460. doi: $10.1016 /$ j.isci.2020.101460

182. Toustrup K, Sorensen BS, Metwally MA, Tramm T, Mortensen LS, Overgaard J, et al. Validation of a 15-gene hypoxia classifier in head and neck cancer for prospective use in clinical trials. Acta Oncol (2016) 55(910):1091-8. doi: 10.3109/0284186X.2016.1167959

183. Lukovic J, Han K, Pintilie M, Chaudary N, Hill RP, Fyles A, et al. Intratumoral heterogeneity and hypoxia gene expression signatures: Is a single biopsy adequate? Clin Transl Radiat Oncol (2019) 19:110-5. doi: 10.1016/j.ctro.2019.09.006

184. Schmidt S, Linge A, Grosser M, Lohaus F, Gudziol V, Nowak A, et al. Comparison of GeneChip, nCounter, and Real-Time PCR-Based Gene Expressions Predicting Locoregional Tumor Control after Primary and Postoperative Radiochemotherapy in Head and Neck Squamous Cell Carcinoma. J Mol Diagn (2020) 22(6):801-10. doi: 10.1016/j.jmoldx. 2020.03.005

185. Betts GN, Eustace A, Patiar S, Valentine HR, Irlam J, Ramachandran A, et al. Prospective technical validation and assessment of intra-tumour heterogeneity of a low density array hypoxia gene profile in head and neck squamous cell carcinoma. Eur J Cancer (2013) 49(1):156-65. doi: 10.1016/ j.ejca.2012.07.028

186. Newman AM, Liu CL, Green MR, Gentles AJ, Feng W, Xu Y, et al. Robust enumeration of cell subsets from tissue expression profiles. Nat Methods (2015) 12(5):453-7. doi: 10.1038/nmeth.3337

187. Yoshihara K, Shahmoradgoli M, Martinez E, Vegesna R, Kim H, TorresGarcia W, et al. Inferring tumour purity and stromal and immune cell admixture from expression data. Nat Commun (2013) 4:2612. doi: 10.1038/ ncomms 3612

188. Chang WH, Forde D, Lai AG. A novel signature derived from immunoregulatory and hypoxia genes predicts prognosis in liver and five other cancers. J Transl Med (2019) 17(1):14. doi: 10.1186/s12967-019$1775-9$

189. Brooks JM, Menezes AN, Ibrahim M, Archer L, Lal N, Bagnall CJ, et al. Development and Validation of a Combined Hypoxia and Immune 
Prognostic Classifier for Head and Neck Cancer. Clin Cancer Res (2019) 25 (17):5315-28. doi: 10.1158/1078-0432.CCR-18-3314

190. Zheng S, Zou Y, Liang JY, Xiao W, Yang A, Meng T, et al. Identification and validation of a combined hypoxia and immune index for triple-negative breast cancer. Mol Oncol (2020) 14:2814-33. doi: 10.1002/1878-0261.12747

191. McDermott D, Lebbé C, Hodi FS, Maio M, Weber JS, Wolchok JD, et al. Durable benefit and the potential for long-term survival with immunotherapy in advanced melanoma. Cancer Treat Rev (2014) 40 (9):1056-64. doi: 10.1016/j.ctrv.2014.06.012

192. Pitt JM, Vétizou M, Daillère R, Roberti MP, Yamazaki T, Routy B, et al. Resistance Mechanisms to Immune-Checkpoint Blockade in Cancer: Tumor-Intrinsic and -Extrinsic Factors. Immunity (2016) 44(6):1255-69. doi: 10.1016/j.immuni.2016.06.001

193. Chang WH, Lai AG. The hypoxic tumour microenvironment: A safe haven for immunosuppressive cells and a therapeutic barrier to overcome. Cancer Lett (2020) 487:34-44. doi: 10.1016/j.canlet.2020.05.011
194. Xu Q, Gu J, Lv Y, Yuan J, Yang N, Chen J, et al. Angiogenesis for tumor vascular normalization of Endostar on hepatoma 22 tumor-bearing mice is involved in the immune response. Oncol Lett (2018) 15(3):3437-46. doi: $10.3892 / \mathrm{ol} .2018 .7734$

Conflict of Interest: The authors declare that the research was conducted in the absence of any commercial or financial relationships that could be construed as a potential conflict of interest.

Copyright $\odot 2021$ Abou Khouzam, Brodaczewska, Filipiak, Zeinelabdin, Buart, Szczylik, Kieda and Chouaib. This is an open-access article distributed under the terms of the Creative Commons Attribution License (CC BY). The use, distribution or reproduction in other forums is permitted, provided the original author(s) and the copyright owner(s) are credited and that the original publication in this journal is cited, in accordance with accepted academic practice. No use, distribution or reproduction is permitted which does not comply with these terms. 